Research papers

\title{
Particulate organic matter dynamics in coastal systems of the northern Beibu Gulf
}

\author{
David Kaiser ${ }^{\mathrm{a}, *}$, Daniela Unger ${ }^{\mathrm{a}, 1}$, Guanglong Qiu ${ }^{\mathrm{b}, \mathrm{c}}$ \\ ${ }^{a}$ Wetland Dynamics Group, Biogeochemistry \& Geology Department, Leibniz Center for Tropical Marine Ecology, D-28359 Bremen, Fahrenheitstr. 6-8, Germany \\ ${ }^{\mathrm{b}}$ Guangxi Mangrove Research Center, Guangxi Marine Environment \& Coastal Wetland Research Center, Beihai 536000, 92 Chang Qing Dong Lu, Guangxi, China \\ ' State Key Laboratory of Urban and Regional Ecology, Research Center for Eco-environmental Sciences, Chinese Academy of Sciences, Beijing 100085, \\ 18 Shuangqing Lu, Haidian District, China
}

\section{A R T I C L E I N F O}

\section{Article history:}

Received 6 July 2013

Received in revised form

2 April 2014

Accepted 7 April 2014

Available online 18 April 2014

\section{Keywords:}

Riverine particle fluxes

$\delta^{13} \mathrm{C}$ and $\delta^{15} \mathrm{~N}$

Amino acids

Land-use

Human impact

Guangxi coast

\begin{abstract}
A B S T R A C T
Estuarine particle fluxes are an integral part of land-ocean-connectivity and influence coastal environmental conditions. In areas with strong anthropogenic impact they may contribute to coastal eutrophication. To investigate the particulate biogeochemistry of a human affected estuary, we sampled suspended, sedimentary and plant particulate matter along the land-ocean continuum from Nanliu River to Lianzhou Bay in southern China. Riverine particle fluxes exceed inputs from land based pond aquaculture. Elemental $(\mathrm{C} / \mathrm{N})$ and isotopic composition of particulate organic carbon $\left(\delta^{13} \mathrm{C}\right)$ and total nitrogen $\left(\delta^{15} \mathrm{~N}\right)$ showed that suspended and sedimentary organic matter $(\mathrm{OM})$ mainly derive from freshwater and marine phytoplankton, with minor contributions from terrestrial and aquaculture derived particles. Amino acid composition indicates subseasonal variability of production and freshness of phytoplankton OM. Strongest compositional changes of suspended particles are associated with storm-related extreme precipitation events, which introduce soil derived OM. High concentrations of chlorophyll $a$ reflect eutrophic conditions in riverine and coastal waters. Human impact results in high $\delta^{15} \mathrm{~N}$ signals in suspended, sedimentary and plant particulate matter. Using these in a comparison with two little affected sites shows that anthropogenic influence disperses from the Nanliu River to remote estuaries and mangrove areas. Our results suggest that autochthonous production binds anthropogenic nutrients in particles that are transported along the coast.
\end{abstract}

(c) 2014 Elsevier Ltd. All rights reserved.

\section{Introduction}

Rivers and estuaries connect continents and oceans, and annually transport $150-205 \times 10^{6} \mathrm{t}$ of particulate organic carbon (POC) (Beusen et al., 2005; Hedges et al., 1997; Meybeck and Vorosmarty, 1999; Seitzinger et al., 2005) and 21-23 $\times 10^{6} \mathrm{t}$ of particulate nitrogen (PN) (Meybeck, 1982; Seitzinger et al., 2002a) from land to sea. Contrary to the numerous investigations of carbon fluxes and dynamics, few studies have focused on particulate nitrogen (Seitzinger et al., 2002a), the most critical element in nutrient enrichment and eutrophication of coastal ecosystems (Seitzinger et al., 2002b).

\footnotetext{
* Corresponding author. Present address: Leibniz Institute for Baltic Sea Research Warnemünde, D-18119 Rostock, Seestraße 15, Germany. Tel.: + 493815197 306; fax: + 493815197440

E-mail addresses: david.kaiser@io-warnemuende.de, david.kaiser.82@gmail.com (D. Kaiser), daniela.unger@desy.de (D. Unger), qalong@163.com (G. Qiu).

${ }^{1}$ Present address: Deutsches Elektronen-Synchrotron, D-22607 Hamburg, Notkestraße 85, Germany.

Chinese rivers play a major role in global transport of particulate matter into the ocean (Milliman et al., 1984; Seitzinger et al., 2002a; Syvitski et al., 2005; Zhang et al., 1992), but data is mostly available for large rivers although small to medium sized rivers may contribute considerably to particle fluxes (e.g. Kao and Liu, 1997; Lyons et al., 2002; Milliman and Syvitski, 1992). Small rivers are also better suited for investigating processes and dynamics because they respond rapidly to seasonal and subseasonal natural or anthropogenic influences, while in major rivers short term regional changes may be masked by integration over the large catchments (Jennerjahn et al., 2008; Unger et al., 2013).

The particulate organic matter (POM) delivered by rivers is an important component in coastal biogeochemistry (Hedges et al., 1997; Raymond and Bauer, 2001; Wu et al., 2007). Investigations of coastal particle dynamics are challenging due to the large temporal and spatial variability in physical and chemical properties of rivers, estuaries and near shore waters (Raymond and Bauer, 2001). POC stable isotope composition $\left(\delta^{13} \mathrm{C}\right)$ is one tool to delineate organic matter (OM) sources in these systems (e.g. Bristow et al., 2012; Jennerjahn et al., 2008, 2004; Raymond and Bauer, 2001; Savoye et al., 2012). Variability in $\delta^{13} \mathrm{C}$ within and 
between systems is to a large degree due to the relative contribution from different sources (Raymond and Bauer, 2001), because primary producers have $\delta^{13} \mathrm{C}$ values according to their carbon source and assimilation pathway (see e.g. Hedges et al., 1997). These signals change only slightly during heterotrophic processing and degradation of POC and are therefore preserved in food webs and detritus (see Hedges et al., 1997; Middelburg and Herman, 2007; Raymond and Bauer, 2001). However, some POC sources in estuaries may have wide and overlapping ranges of $\delta^{13} \mathrm{C}$. For instance, overlapping values of freshwater phytoplankton $(-34$ to $-26 \%$; Bristow et al., 2012 and references therein), terrestrial C3 plants ( -33 to $-22 \%$; Bender, 1971) and sewage ( -28 to $-23 \%$; Andrews et al., 1998; Thornton and McManus, 1994) hamper the discrimination of autochthonous, terrestrial, or anthropogenic material in rivers. The elemental carbon to nitrogen ratio $(\mathrm{C} / \mathrm{N})$ differs between sources because high contents of nitrogen-free biomacromolecules cause high values in vascular plants (C/N 20-500) compared to phytoplankton $(C / N \approx 7)$, bacteria $(C / N \approx 4)$ and fungi $(C / N \approx 10)$ (Hedges et al., 1986). The use of $\mathrm{C} / \mathrm{N}$ to identify organic matter sources is complicated because it changes during degradation. While terrestrial vascular plant $\mathrm{C} / \mathrm{N}$ tends to decrease due to colonization with bacteria, algal detritus becomes nitrogen depleted due to preferential consumption of $\mathrm{N}$-containing molecules (Middelburg and Herman, 2007). These restrictions may be overcome by combined use of both indicators (Bristow et al., 2012; Raymond and Bauer, 2001).

The stable isotope signature of $\mathrm{PN}\left(\delta^{15} \mathrm{~N}\right)$ may not be a suitable indicator for OM sources within one system because $\delta^{15} \mathrm{~N}$ of different sources can overlap (see e.g. Bristow et al., 2012; Maksymowska et al., 2000; Middelburg and Nieuwenhuize, 1998 and references therein) as it depends strongly on the $\delta^{15} \mathrm{~N}$ of the original dissolved nitrogen assimilated into OM (Cifuentes et al., 1988; Liu et al., 2007). Processes like nitrification, denitrification, assimilation, and ammonification (Cifuentes et al., 1989; Granger et al., 2010, 2008, 2004) as well as OM degradation (Lehmann et al., 2002) change a source's $\delta^{15} \mathrm{~N}$ due to isotope fractionation, i.e. the preferential uptake or removal of the lighter, more mobile ${ }^{14} \mathrm{~N}$ isotope during thermodynamic and physiological processes. These changes can, thus, be used to assess nitrogen processing (e.g. Middelburg and Herman, 2007). Also, $\delta^{15} \mathrm{~N}$ can work as a footprint for nitrogen inputs, particularly when comparing variability between different systems (Robinson, 2001). Betweensystem variability mostly depends on $\delta^{15} \mathrm{~N}$ of original local nitrogen sources and effects of nitrogen conversion processes are less pronounced than within systems (Robinson, 2001). Thus, the $\delta^{15} \mathrm{~N}$ of suspended particles, sediments, micro and macro algae, and higher plants have been used successfully to trace nitrogen sources, including anthropogenic inputs, in different systems (e.g. Abreu et al., 2006; Bao et al., 2013; Costanzo et al., 2005, 2004, 2003, 2001; Harrington et al., 1998). Nitrogen transformations in human affected watersheds cause a depletion of ${ }^{14} \mathrm{~N}$ (e.g. Anderson and Cabana, 2006). Thus, high anthropogenic influence resulting in strong nitrogen loading to aquatic systems is accompanied by elevated $\delta^{15} \mathrm{~N}$ (e.g. Middelburg and Herman, 2007). These high values can be traced from areas directly affected by aquaculture to remote systems (e.g. Costanzo et al., 2001; Herbeck and Unger, 2013).

The identification of OM sources may be further improved by using the composition of amino acids (AA), which account for $>30 \%$ of organic carbon and about 60 to $80 \%$ of the nitrogen in marine particles and plankton (Cowie and Hedges, 1992; Dauwe and Middelburg, 1998; Van Mooy et al., 2002), rendering them representative for most $\mathrm{OM}$. The reactivity of AA varies between monomers and the degree of OM degradation is mirrored in the Degradation Index (DI; Dauwe et al., 1999) and Reactivity Index (RI; ratio of proteinogenic to non-proteiongenic AA; Jennerjahn and Ittekkot, 1999). High values of DI and RI indicate high OM reactivity, and values decrease with progressing degradation. Amino sugars (AS) are less abundant and less reactive than AA, so that advanced degradation is reflected in decreasing AA/AS ratios (Benner and Kaiser, 2003; Gupta and Kawahata, 2000; Haake et al., 1992; Müller et al., 1986).

In this study, we use carbon and nitrogen ratios and isotopic composition as well as amino acid characteristics of suspended, sedimentary, and plant particulate matter to understand $\mathrm{OM}$ dynamics within the small Nanliu River estuary and between three different coastal sites along the coast of Guangxi province in southern China. Coastal China is among the most densely populated and rapidly developing regions on earth. Coastal development has caused the loss of $>60 \%$ of Chinas mangrove systems ( $\mathrm{Li}$ and Lee, 1997), mostly due to conversion to aquaculture facilities (Bao et al., 2013). The effects of human enhanced nutrient and organic matter fluxes on coastal productivity are still poorly understood in China (Wu et al., 2007), but there is evidence for increased coastal eutrophication (e.g. Cai et al., 2004; Chen and Hong, 2011; Herbeck et al., 2012; Hodgkiss and Ho, 1997; Kaiser et al., 2013; Yuan et al., 2012).

\section{Material and methods}

\subsection{Study sites and sampling}

Guangxi Province in southern China has a coastline of $1164 \mathrm{~km}$ (www.nanning.gov.cn, 2010) along the northern Beibu Gulf, the north-western part of the South China Sea (Fig. 1). This subtropical coast is influenced by the East Asian monsoon with dry boreal winter-spring and wet boreal summer-autumn seasons (Wu et al., 2008). Long term average annual precipitation is $179 \mathrm{~cm} \mathrm{yr}^{-1}$ but was considerably lower at $152 \mathrm{~cm} \mathrm{yr}^{-1}$ during the study period (Climate.usurf.usu.edu, Beihai meteorological station, 1954-2011). During the rainy season daily precipitation is highly variable with periods of no rainfall. Tropical cyclones occur up to 5 times a year between May and November and cause short term climatic and hydrographic extremes (Committee of Annals of Chinese Estuaries, 1998, p. 65). Coinciding with our fieldwork, a tropical storm originating from typhoon Nesat passed the coast on 1 October 2011 and caused extreme winds and precipitation (Fig. 2).

With a length of $287 \mathrm{~km}$ and average discharge of $5.313 \times$ $10^{9} \mathrm{~m}^{3} \mathrm{yr}^{-1}$ (Chen et al., 2007), the small Nanliu River is the longest river in Guangxi Province with the highest discharge. The catchment area of $9704 \mathrm{~km}^{2}$ (Dai et al., 2011) is dominated by agriculture of mainly rice and sugar cane. Zonation based on salinity distribution and geography divides the macrotidal estuary into river, inner and outer estuary, and bay (Kaiser et al., 2013). In the estuary, the mangroves Aegiceras corniculatum and Kandelia candel cover intertidal islands and river banks. Deforestation has decreased the forest area from 1790 ha in the early 1990s (Li and Lee, 1997) to only approximately 515 ha in 2011, mainly due to conversion into aquaculture ponds. Approximately 6500 ha of brackish water shrimp culture cover the landward area of the inner estuary. They are mostly enclosed by flood protection dykes and connected to the estuary via drainage channels. With operations suspended during dry season, pond effluents are discharged only twice annually after harvest during the wet season. The semienclosed Lianzhou Bay covers an area of $237 \mathrm{~km}^{2}, 70 \%$ of which comprise the shallow subtidal sandbanks of the outer estuary (Jiang et al., 2008), and tidally exchanges water with the Beibu Gulf across a $24.4 \mathrm{~km}$ wide opening (Sun et al., 2014). Along the coast mixed diurnal-semidiurnal tides have a range of up to $5.36 \mathrm{~m}$ (Committee of Annals of Chinese Estuaries, 1998). 
a
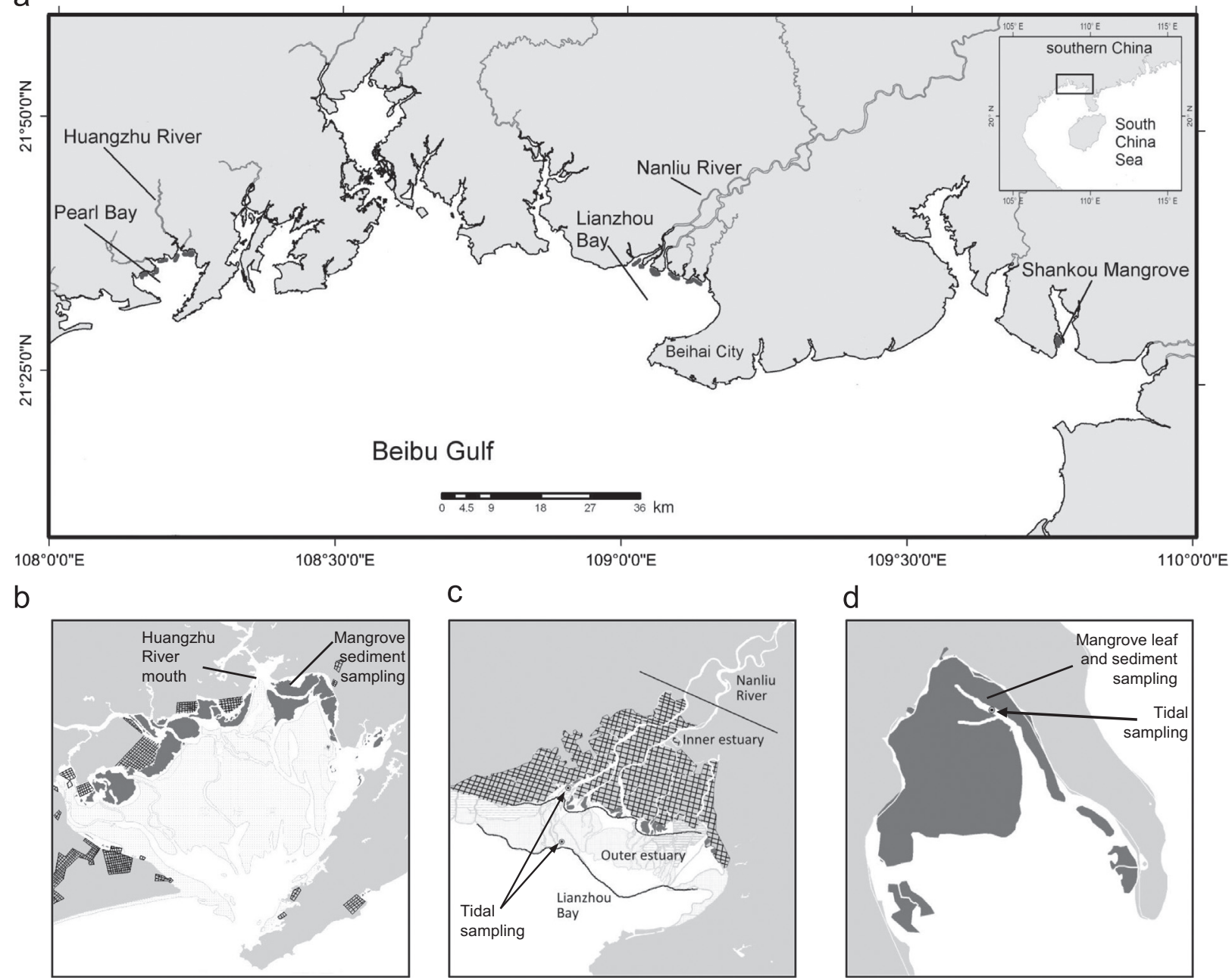

Fig. 1. Map of the Guangxi coast (a) showing the location three study areas. Inlay shows the regional position of the study site. Detail maps show Huangzhu River/Pearlbay (b), Nanliu River/Lianzhou Bay (c) and Shankou Mangrove (d); scale is different for each map. Dark gray areas represent the location of intertidal mangrove areas. Aquaculture ponds are marked by black lattice in (b); in (c) the black lattice shows the area encompassing $>6500$ ha of aquaculture ponds. In c and d concentric symbols shows tidal sampling stations and are indicated by arrows. Zones are marked in (c) corresponding to Fig. 3.

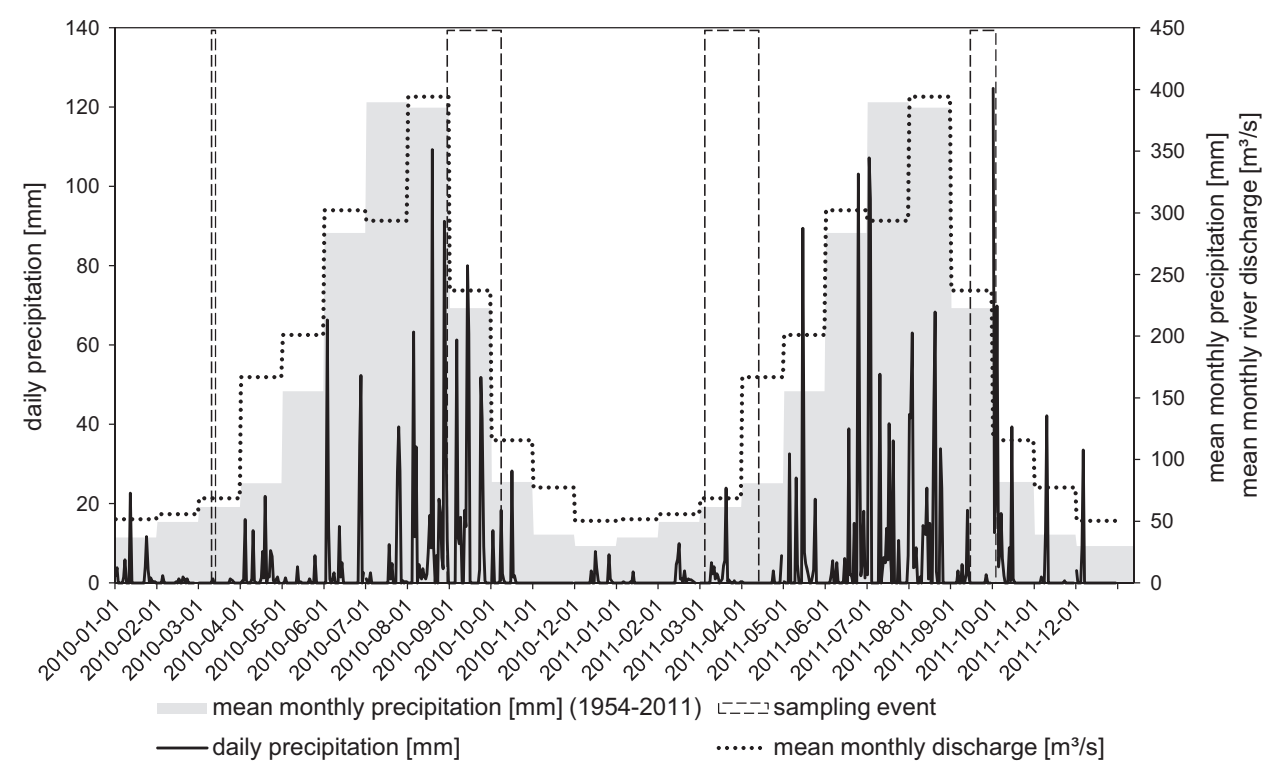

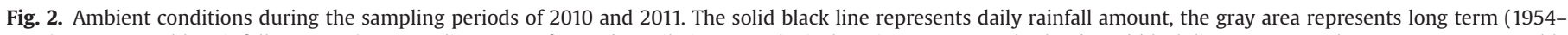

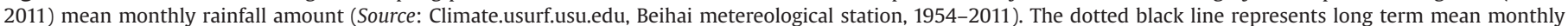
river discharge (Chen, 1997). Dashed black frames represent seasonal sampling periods. 
Located about $85 \mathrm{~km}$ west of Nanliu Estuary, the Huangzhu River is a smaller, clear river debouching into Pearl Bay, which opens to the Beibu Gulf through a narrow, $3.3 \mathrm{~km}$ wide, passage (Fig. 1). The hilly catchment area is unsuitable for large scale agrior aquaculture and human activities concentrate on eucalyptus silviculture. Estuarine mangrove areas are larger than in the Nanliu/Lianzhou area and protected as part of the Beilun Estuary National Level Reserve. The Shankou Mangrove Reserve is located About $75 \mathrm{~km}$ east of Nanliu Estuary (Fig. 1). This relatively undisturbed mangrove forest covers the outer part of a bay surrounded by steep hills and has no direct river influence. The inner part is occupied by a small area of wet rice agriculture. Hydrodynamics are governed by macrotidal exchange with the Beibu Gulf.

During Aug.-Oct. 2010, and Feb.-Apr. and Aug.-Oct. 2011 surface water was sampled during high tide along transects encompassing the Nanliu River, its inner and outer estuary, and Lianzhou Bay. Five to 10 stations were sampled along each of the three branches of the estuary. The 10 stations in Lianzhou Bay and the outer estuary were sampled on different days than the river and inner estuary due to tidal conditions and the accessibility of the area. Data obtained in the three estuarine branches were combined according to the zone-system described above (i.e. pooled into river, inner and outer estuary, and bay) (compare Figs. 1 and 3; Kaiser et al., 2013). Bottom or river bank surface sediments were sampled at several stations along the branches of the estuary during each season. The exact location of repeated sampling varied slightly depending on accessibility of sediments but generally encompassed the estuarine gradient. Additional water samples were taken from shrimp ponds along the landward side of the inner estuary, covering different stages of the production cycle. Mangroves were sampled for fresh leaves and surface sediments; most stations were sampled repeatedly but additional samples were obtained when feasible during individual outings.

In spring and summer 2011, tidal sampling was carried out during diurnal spring and semi-diurnal neap tides at one fixed station in a mangrove fringed channel of the Nanliu Estuary near the mouth of the main river branch and one at the boundary between outer estuary and bay (see Fig. 1). Water samples were taken hourly for $24 \mathrm{~h}$. During tidal samplings, we calculated surface current velocity as the average of triplicate floating time of a half filled water bottle attached to a $10 \mathrm{~m}$ soft thread. In March 2010 surface water was sampled in the Huangzhu and along its estuary with endmembers in the freshwater part and off the river mouth (Fig. 1); leaves and sediments were obtained from mangroves of Pearl Bay, just east of the Huangzhu Estuary. In the Shankou Mangrove area, water samples were taken during tidal sampling in April 2011 at one station in a large tidal channel; simultaneously surface sediments were sampled from mangroves fringing the channel.

\subsection{Sample preparation and analysis}

Water temperature, salinity, and $\mathrm{pH}$ were measured instantly using a Hach-Lange HQ40D multisensor. Dissolved oxygen was measured directly in the surface waters using a Hach-Lange LD0101 optode. Water depth and transparency were measured with a handheld echo sounder (Echotest II) and a Secchi disk, respectively. All water samples were stored cool and dark in sample-rinsed $10 \mathrm{~L}$ PE canisters during field excursions and filtered onto pre-combusted ( $>4 \mathrm{~h}$ at $450{ }^{\circ} \mathrm{C}$ ) and pre-weighted $\mathrm{GF} / \mathrm{F}$ glass fiber filters with a nominal pore size of $0.45 \mu \mathrm{m}$ as soon as possible, generally within $24 \mathrm{~h}$. Between 250 and $1000 \mathrm{~mL}$ were filtered depending on SPM concentrations; in some cases aquaculture sample volume was as low as $100 \mathrm{~mL}$. Filters for SPM, sediments, and leaves were dried at $40{ }^{\circ} \mathrm{C}$ to constant weight and stored together with hydrophilic silica until analysis at the Leibniz Center for Tropical Marine Ecology (ZMT), Bremen, Germany, within 10 weeks. For phytopigment analysis triplicate samples were filtered onto GF/F filters and frozen in aluminum foil.

Chlorophyll $a$ content of SPM was analyzed in the laboratory of the Guangxi Mangrove Research Center (GMRC), Beihai, using a Raylight UV-1801 automatic spectrophotometer. Corrected and uncorrected concentrations of chlorophyll $a$ were determined on triplicate filters by standard trichromatic methods as described by French (2010). In brief, pigments were extracted in 90\% acetone in the dark at $4{ }^{\circ} \mathrm{C}$ over night. After centrifugation, the absorbance of the extract was measured against 90\% acetone at 630, 647, 664, 665 , and $750 \mathrm{~nm}$ before and $60 \mathrm{~s}$ after acidification with hydrochloric acid. Pretests had shown that absorbance of the extracts does not change between 60 or $90 \mathrm{~s}$ after acidification. Formulas given by Lorenzen (1967) and Jeffrey and Humphrey (1975) were used for calculations of pigment concentrations.

Before analysis of particulate matter at the laboratory in Bremen, Germany, all samples were re-dried for $24 \mathrm{~h}$ at $40{ }^{\circ} \mathrm{C}$; sediment and leaf samples were homogenized in a Retsch PM100 planetary mill and Retsch CM centrifugal mill, respectively. Total carbon (TC) and nitrogen (TN) content of all samples were analyzed by high-temperature combustion in a Carlo Erba NA 2100 elemental analyzer. Organic carbon (OC) was analyzed similarly after removal of inorganic carbon by acidification with $1 \mathrm{~N}$ hydrochloric acid and subsequent drying at $40{ }^{\circ} \mathrm{C}$. Precision of the measurements, as relative standard deviation of repeated measurements of OAS standard material, was 3.8\% for OC and $2.4 \%$ for TN. For plant material apple leaf standard was used and relative standard deviations were $1.7 \%$ for OC and $2.7 \%$ for TN. The isotopic composition of $\mathrm{OC}\left(\delta^{13} \mathrm{C}\right)$ and $\mathrm{TN}\left(\delta^{15} \mathrm{~N}\right)$ was determined with a Thermo Finnigan Delta Plus gas isotope ratio mass spectrometer following high-temperature combustion in a Flash 112EA elemental analyzer. Samples for $\delta^{13} \mathrm{C}$ were acidified as described for OC while $\delta^{15} \mathrm{~N}$ was determined on non-acidified samples as acidification may significantly alter $\delta^{15} \mathrm{~N}$ of the sample (e.g. Kennedy et al., 2005).Values of $\delta^{13} \mathrm{C}$ and $\delta^{15} \mathrm{~N}$ were determined according to $\delta$ $[\% o]=\left(R_{x} / R_{S}-1\right) 1000$, where $R_{x}$ and $R_{S}$ denote the ratios of heavy to light isotopes (i.e. ${ }^{13} \mathrm{C} /{ }^{12} \mathrm{C}$ or ${ }^{15} \mathrm{~N} /{ }^{14} \mathrm{~N}$ ) of the sample and a standard material, respectively (e.g. Kendall and Caldwell, 1998; Peterson and Fry, 1987). Values are given in \%o-denotation in reference to the PDB standard and atmospheric nitrogen, respectively. Analytical precision, as standard deviation of repeated measurements of a pepton standard, was 0.09 and $0.14 \%$, respectively.

SPM from the Nanliu Estuary was analyzed for its total content of hydrolysable amino acids (AA) and hexosamines (amino sugars, AS) by chromatographic separation in a Biochrom 30 amino acid analyzer following hydrolysation with $6 \mathrm{~N}$ hydrochloric acid for $2 \mathrm{~h}$ at $110{ }^{\circ} \mathrm{C}$. To compensate for losses during hydrolysis, AS concentrations were corrected with a factor of 1.4 (Müller et al., 1986). After derivatisation with 0 -Phtaldialdeheyd and mercaptoethanol the following monomers were detected fluorometrically: alanine (ALA), arginine (ARG), aspartic acid (ASP), glutamic acid (GLU), glycine (GLY), histidine (HIS), isoleucine (ILE), leucine (LEU), lysine (LYS), methionine (MET), ornithine (ORN), phenylalanine (PHE), serine (SER), taurine (TAU), threonine (THR), tyrosine (TYR), valine (VAL); $\beta$-alanine (b-ALA), $\gamma$-aminobutyric acid (g-ABA); galactosamine (GALAM); glucosamine (GLUAM). Based on repeated standard solution measurements relative standard deviation of monomer concentrations was $0.1-2.5$ (average 0.8 )\%, except of ORN for which it was $2.2-4.6 \%$. Since ORN contributes $<2 \%$ of total AA and is not included in degradation or reactivity index the low precision has negligible effects on data evaluation. The Reactivity Index (RI) was calculated as the molar ratio of TYR + PHE to the non-proteinogenic AA b-ALA+gABA following Jennerjahn and Ittekkot (1999). As an additional indicator for 
a

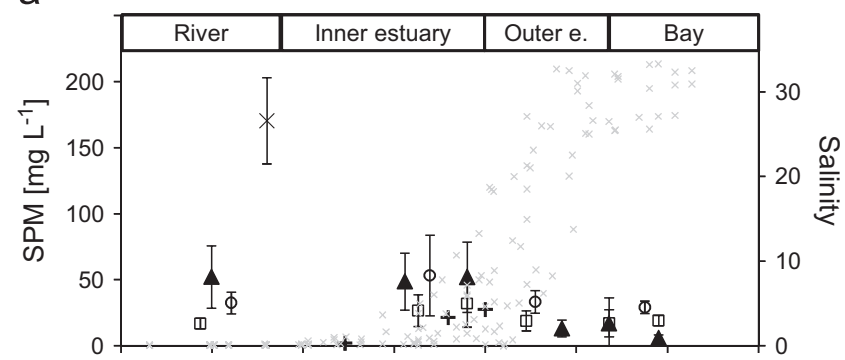

C

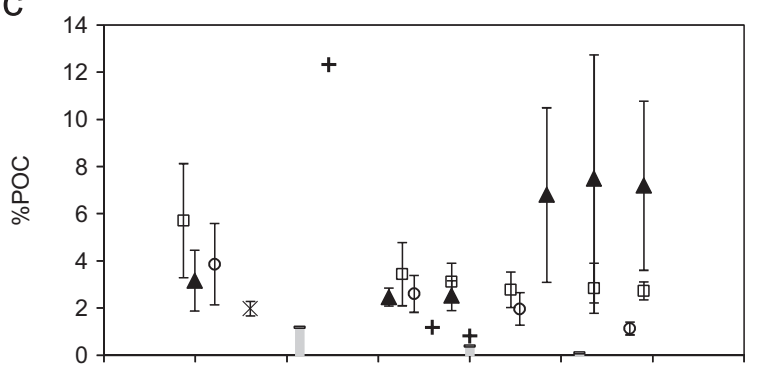

e

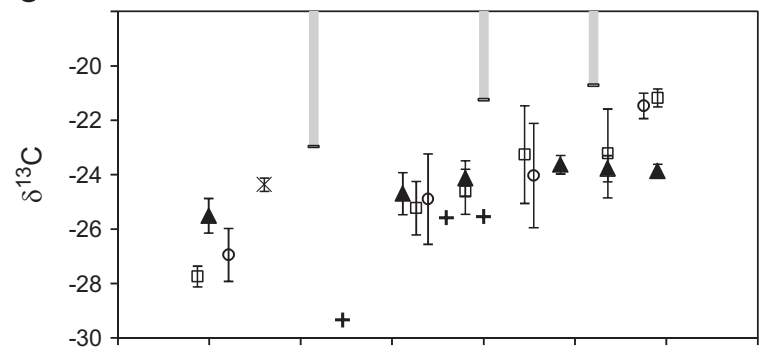

g

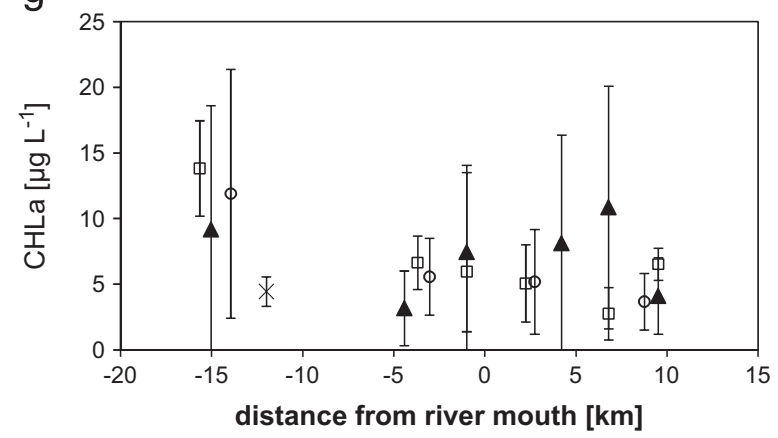

b

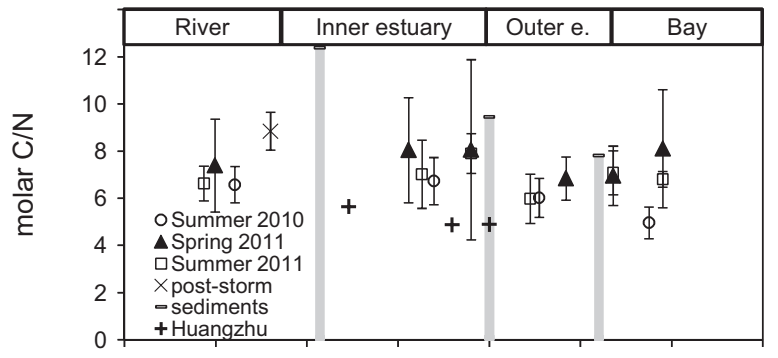

d

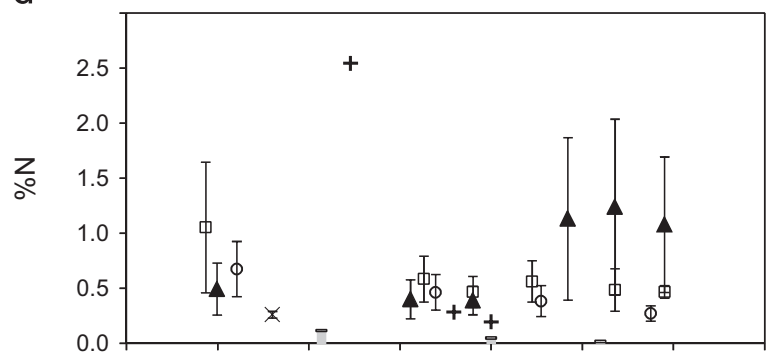

$f$

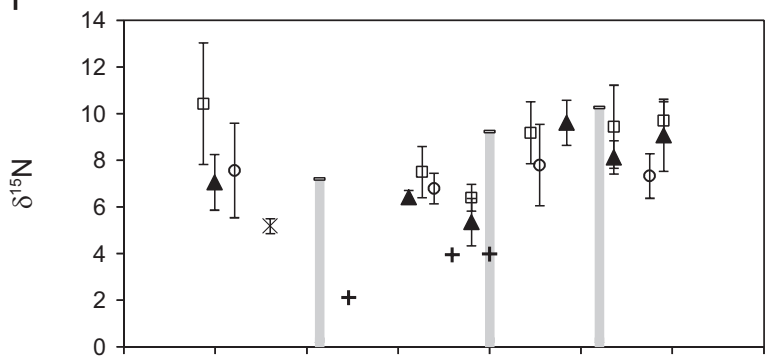

$\mathrm{h}$

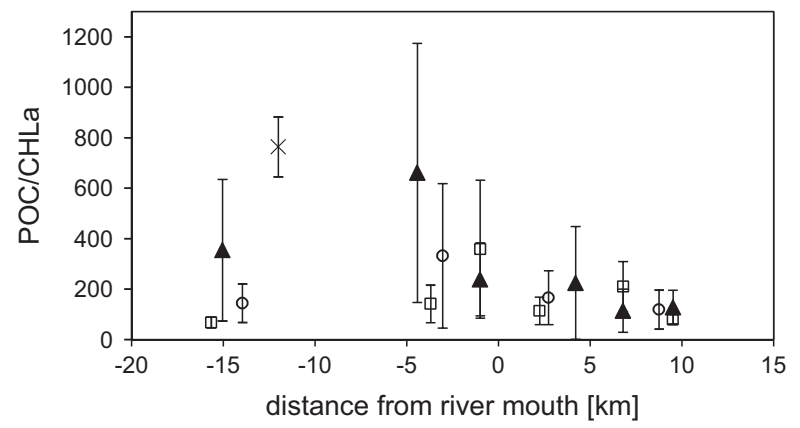

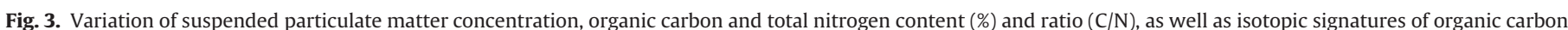

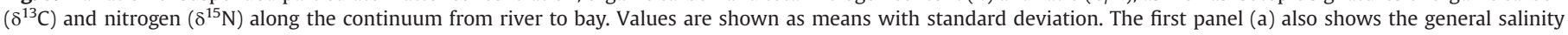

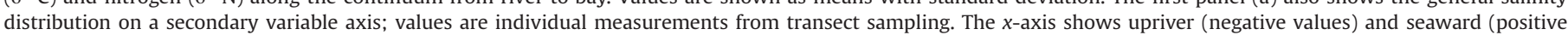

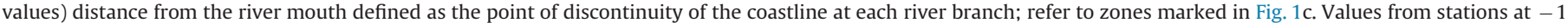

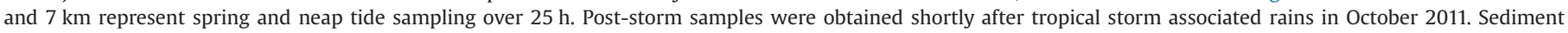

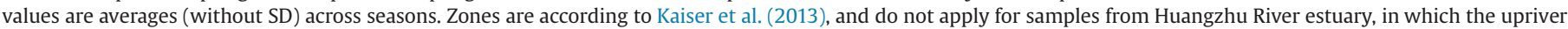
most sample was obtained from freshwater.

organic matter degradation we calculated the Degradation Index (DI; using molar percentages of ASP, THR, SER, GLU, GLY, ALA, VAL, MET, ILE, LEU, TYR, PHE, HIS, ARG) as described by Dauwe et al. (1999).

In Huangzhu and Shankou, samples for analysis of dissolved inorganic nitrogen (DIN) were directly filtered into HDPE bottles through disposable mixed ester-cellulose filters with a nominal pore size of $0.45 \mu \mathrm{m}$ and preserved with mercury chloride. Samples were kept on ice in the dark during field excursions and were frozen upon arrival at the laboratory in Beihai. Analyses were done spectrophotometrically for nitrate and nitrite, and fluorometrically for ammonium at the laboratory of the ZMT. For a full description of methods and a discussion of nutrient dynamics in the Nanliu Estuary see Kaiser et al. (2013).

For statistical tests we used the SigmaPlot 12.3 software package. One-way ANOVAs were employed to test for differences between zones during one season and/or for temporal differences within one zone as well as between clusters. Two-way ANOVAs were used for differences in isotopic composition of mangroves from different species and sites. Significantly different groups were identified by Student-Newman-Keul's post-hoc method. We used t-tests to compare pre and post-storm SPM composition in Nanliu River and high and low tide samples in Shankou Mangrove. Significance level is $P \leq 0.05$. Where assumptions for parametric 
statistics were violated data was root of log transformed before testing. See Supplementary table for ANOVA results. In the rare cases where transformations did not yield normal distribution and equal variance, nonparametric tests were employed. This was the case for most comparisons of river and bay characteristics with aquaculture properties during individual campaigns. Significance level for Kruskal-Wallis ANOVAs was also $\leq 0.05$. For testing the correlation of parameters we used linear regression and report the square of Pearson product moment correlation coefficient $\left(R^{2}\right)$. We report $R^{2}$ as the coefficient of determination to give a first order estimate of the percentage of the dependent variable explained by changes in the independent variable. A Cluster Analysis (Euclidean distance, Ward's method) was performed in STATISTICA 11 on SPM samples from the Nanliu River, inner and outer estuary, and Lianzhou Bay, using SPM and chlorophyll a concentrations, OC (\%POC), TN (\%N), the molar $\mathrm{C} / \mathrm{N}$ ratio, $\delta^{13} \mathrm{C}, \delta^{15} \mathrm{~N}$, and salinity as variables.

\section{Results}

\subsection{Suspended particulate matter}

In Nanliu River (Fig. 1), SPM concentrations ranged between 9.5 and $211 \mathrm{mg} \mathrm{L}^{-1}$, with highest concentrations of $>100 \mathrm{mg} \mathrm{L}^{-1}$ following the tropical storm in October 2011 (Fig. 3). Excluding these extreme values, concentrations were significantly higher during spring than summer (Fig. 3; one-way ANOVA, $P<0.05$ ). The organic carbon (\%POC, $1.6-10.2 \%)$ and total nitrogen $(\% \mathrm{~N}, 0.2-$ $2.2 \%$ ) contents of riverine SPM were higher during summer than spring. Chlorophyll $a$ (CHLa) was extremely variable (1.3-31.2 $\mu$ $\mathrm{g} \mathrm{L}^{-1}$ ) and higher during summers but minimal after extreme precipitation (Fig. 3, Table 1). There was no significant seasonal difference in carbon and nitrogen elemental $(\mathrm{C} / \mathrm{N})$ and isotopic ratios $\left(\delta^{13} \mathrm{C}\right.$ and $\delta^{15} \mathrm{~N}$, respectively) when post-storm data is included (Table 1; One-way ANOVA, $P>0.05$ ), but there was a significant difference between pre and post-storm C/N (6.63 vs. 8.64), $\delta^{13} \mathrm{C}$ ( -27.74 vs. $-24.36 \%$ ), and $\delta^{15} \mathrm{~N}(10.44$ vs. $5.07 \%$ o $)$ in summer 2011 (Fig. 3 ; $t$-test, $P<0.05$ ). Concentrations of SPM did not decrease significantly between zones except from inner to outer estuary during spring. Minimum and maximum SPM concentrations (excluding post-storm values) occurred during tidal station samplings, with higher concentrations during low than high tide (Fig. 4). In Lianzhou Bay (Fig. 1) concentrations ranged between 4.5 and $31.4 \mathrm{mg} \mathrm{L}^{-1}$, and were significantly different between all seasons (Fig. 3, Table 1). Off the river mouth \%POC and $\% \mathrm{~N}$ were higher during spring (Table 1 ), coinciding with high CHLa concentrations of up to $26 \mu \mathrm{g} \mathrm{L}^{-1}$ in the outer estuary (Fig. 3), and up to $46 \mu \mathrm{g} \mathrm{L}^{-1}$ at the outer tidal sampling station (Fig. 4). $\delta^{13} \mathrm{C}$ and $\delta^{15} \mathrm{~N}$ were higher in coastal waters relative to the inner estuary but $\mathrm{C} / \mathrm{N}$ did not change (Fig. 3). Throughout the system the contributions of amino acids to POC (AA-C\%) and PN (AA-N\%) ranged between $11.6-47.7$ and $8.7-84.3 \%$, respectively. Both values increased from the river to the bay during spring but decreased during summer (Table 2). There was no strict seasonal pattern and $\mathrm{AA}-\mathrm{C} \%$ and $\mathrm{AA}-\mathrm{N} \%$ did not decrease significantly after extreme rain (Table 2).

Summer SPM concentrations in aquaculture ponds at the Nanliu Estuary exceeded river and bay concentrations and contained higher \%POC and \%N, as well as highest concentrations of CHLa (Table 1). The $\mathrm{C} / \mathrm{N}$ (Table 1 ) as well as $\mathrm{AA}-\mathrm{C} \%$ and $\mathrm{AA}-\mathrm{N} \%$ (Table 2) of aquaculture SPM was similar to that in the estuary and $\delta^{13} \mathrm{C}$ was intermediate between river and bay values (Table 1 ). Values of $\delta^{15} \mathrm{~N}$ were lower than elsewhere in the system (Table 1 , Fig. 3). Aquaculture values for spring are also given in Table 1 for completeness, but are not discussed in the following as they have negligible effect on particulate dynamics due to low effluent discharge during spring season (see Section 2.1).

In Huangzhu River (Fig. 1), SPM concentration was low (2.02 $\mathrm{mg} \mathrm{L}^{-1}$ ) but increased along the estuary to values similar to those in the Nanliu Estuary(Table 1, Fig. 3). Contrarily, \%POC and $\% \mathrm{~N}$ were higher in Huangzhu than Nanliu River but decreased in the estuary (Fig. 3), where the lowest values in the study region were measured (Table 1). The decrease was stronger for \%POC than $\% \mathrm{~N}$, resulting in a decrease of $\mathrm{C} / \mathrm{N}$ to values below those in the Nanliu Estuary. SPM showed the lowest $\delta^{13} \mathrm{C}$ and $\delta{ }^{15} \mathrm{~N}$ measured throughout the study region (Table 1, Fig. 3).

In the Shankou Mangrove (Fig. 1), we regard low tide values as representative for autochthonous mangrove derived material as samples were obtained during late ebb to early flood tides with minimal marine influence. High tide samples are considered marine as they show significantly different characteristics (Table 1) and were obtained during marine conditions at salinities around 32 (Fig. 5). Low tide mangrove samples had higher SPM concentrations but lower \% $\mathrm{POC}$ and \% $\mathrm{N}$ than high tide marine samples (Table 1). Mangrove samples also were characterized by significantly higher $\mathrm{NH}_{4}$ concentrations but lower $\delta^{15} \mathrm{~N}$ values in SPM (Fig. 5) ( $t$-tests, $P>0.001)$. Marine SPM concentrations and composition were comparable to those in Lianzhou Bay, albeit slightly lower $\delta^{13} \mathrm{C}$ and $\delta^{15} \mathrm{~N}$ (Table 1 ).

\subsection{Cluster analysis}

Cluster analysis identified six distinct groups of SPM in the Nanliu area (Fig. 6, Tables 1 and 2). Cluster 1 (marine) contains most samples from Lianzhou Bay and those from the outer estuary obtained during sampling in Lianzhou Bay, as well as all high tide samples from the outer tidal station. It only comprised few high tide samples from the mangrove tidal station and none from the inner estuary or river zones (Table 3 ). This marine cluster is characterized by highest average salinity (26.6), \%POC (5.29\%), \% PN (0.91\%), $\delta^{15} \mathrm{~N}(8.84 \%$ ), DI (0.69), RI (13.66), AA-N\% (50.70), AA-C\% (28.90), AAmg/g (42.68), and AA/AS (14.35), and lowest average SPM concentration (12.05 $\mathrm{mg} \mathrm{L}^{-1}$ ), POC/CHLa (156.2), and molar POC/PN (6.87). Cluster 2 (outer estuary) has slightly lower salinity than cluster 1 . Samples were mostly obtained during high tide at the mangrove and low tide at the outer tidal stations, as well as from the outer estuary at high salinity, but not from the inner estuary or river (Table 3 ). The cluster also contains samples obtained from Lianzhou Bay in late summer 2011 at the end of a period of bad weather. This cluster showed lowest averages of CHLa concentration $\left(4.0 \mu \mathrm{g} \mathrm{L}^{-1}\right)$, \%POC (1.93\%), and POC/PN (6.79), but highest $\delta^{13} \mathrm{C}(-22.91 \%$ ) (Table 1$)$. Amino acid related values are slightly lower than in cluster 1 (Table 2).

The four remaining clusters do not include any samples from Lianzhou Bay or high tide tidal samplings and thus reflect variations of SPM composition in Nanliu River and its inner estuary (Table 3). Cluster 3 (upriver) includes most river samples, including the most upriver station (32 km upriver from mouth; $n=3$ ), and inner estuary, but few outer estuary samples. It includes low tide samples from the mangrove tidal station but only 2 lowest tide samples from the outer station obtained during the high discharge season. Low average salinity (3.5), SPM $\left(24.88 \mathrm{mg} \mathrm{L}^{-1}\right)$, and $\delta^{13} \mathrm{C}(-25.55 \%$ ) characterize this cluster (Table 1$)$. Cluster 4 (river) has a similar sample site composition as cluster 3, dominated by stations from the river and inner estuary as well as low salinity samples from the outer estuary and tidal samplings. Concentrations of CHLa and SPM are higher than in cluster 3 (Table 1 ) but AA derived values (Table 2 ) and \%POC and \%N (Table 1) are slightly lower. Cluster 5 (resuspension) comprises only few samples, of which most were obtained in the inner 
Table 1

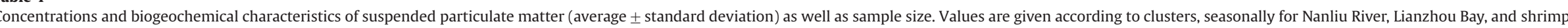

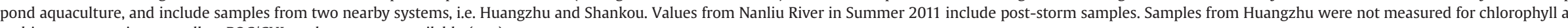
and its concentration as well as POC/CHLa values are not available (n.a.).

\begin{tabular}{|c|c|c|c|c|c|c|c|c|c|c|c|}
\hline & $n$ & $\mathrm{SPM}\left[\mathrm{mg} \mathrm{L}^{-1}\right]$ & $\%$ POC & $\% \mathrm{~N}$ & molar $\mathrm{C} / \mathrm{N}$ & $\delta^{13} \mathrm{C}[\% o]$ & $\delta^{15} \mathrm{~N}[\% o]$ & CHLa $\left[\mu \mathrm{g} \mathrm{L}^{-1}\right]$ & POC/CHLa & $\mathrm{T}\left[{ }^{\circ} \mathrm{C}\right]$ & Salinity \\
\hline \multicolumn{12}{|l|}{ Clusters } \\
\hline Cluster 1 (marine) & 117 & $12.05 \pm 4.56$ & $5.29 \pm 4.22$ & $0.91 \pm 0.68$ & $6.87 \pm 1.18$ & $-23.37 \pm 1.24$ & $8.84 \pm 1.55$ & $6.4 \pm 7.3$ & $156.2 \pm 7.3$ & $22.6 \pm 5.7$ & $26.6 \pm 5.6$ \\
\hline Cluster 2 (outer estuary) & 36 & $32.10 \pm 7.90$ & $1.93 \pm 0.65$ & $0.33 \pm 0.11$ & $6.79 \pm 1.20$ & $-22.91 \pm 0.96$ & $7.70 \pm 1.67$ & $4.0 \pm 3.3$ & $203.7 \pm 3.3$ & $22.6 \pm 5.3$ & $23.2 \pm 4.8$ \\
\hline Cluster 3 (upriver) & 78 & $24.88 \pm 7.66$ & $3.41 \pm 1.32$ & $0.57 \pm 0.26$ & $7.13 \pm 1.27$ & $-25.55 \pm 1.18$ & $6.81 \pm 1.83$ & $5.6 \pm 4.5$ & $276.6 \pm 4.5$ & $25.2 \pm 5.8$ & $3.5 \pm 4.0$ \\
\hline Cluster 4 (river) & 63 & $52.86 \pm 9.43$ & $2.87 \pm 0.86$ & $0.46 \pm 0.16$ & $7.49 \pm 1.24$ & $-24.71 \pm 0.99$ & $6.06 \pm 1.14$ & $10.6 \pm 9.3$ & $287.0 \pm 9.3$ & $22.0 \pm 6.8$ & $4.9 \pm 4.6$ \\
\hline Cluster 5 (resuspension) & 16 & $83.79 \pm 9.53$ & $2.23 \pm 0.36$ & $0.30 \pm 0.08$ & $8.68 \pm 1.07$ & $-23.52 \pm 0.63$ & $6.38 \pm 1.04$ & $6.1 \pm 4.4$ & $458.4 \pm 4.4$ & $17.7 \pm 4.7$ & $7.3 \pm 6.2$ \\
\hline Cluster 6 (post-storm) & 6 & $171.29 \pm 29.26$ & $2.00 \pm 0.28$ & $0.23 \pm 0.08$ & $12.82 \pm 9.74$ & $-23.93 \pm 0.75$ & $5.55 \pm 0.86$ & $4.9 \pm 1.5$ & $721.0 \pm 1.5$ & $22.9 \pm 4.4$ & $1.1 \pm 2.6$ \\
\hline \multicolumn{12}{|l|}{ Nanliu River } \\
\hline Summer 2010 & 9 & $35.30 \pm 11.31$ & $3.65 \pm 1.74$ & $0.66 \pm 0.24$ & $6.33 \pm 1.03$ & $-26.81 \pm 0.99$ & $7.58 \pm 2.03$ & $11.3 \pm 9.0$ & $147.1 \pm 71.9$ & $29.8 \pm 1.5$ & $0.1 \pm 0.0$ \\
\hline Spring 2011 & 11 & $52.16 \pm 23.50$ & $3.17 \pm 1.29$ & $0.49 \pm 0.24$ & $7.40 \pm 1.97$ & $-25.44 \pm 0.67$ & $7.10 \pm 1.27$ & $9.2 \pm 9.4$ & $354.9 \pm 280.8$ & $20.6 \pm 4.8$ & $0.1 \pm 0.0$ \\
\hline Summer 2011 & 10 & $76.04 \pm 78.99$ & $4.17 \pm 2.69$ & $0.73 \pm 0.61$ & $7.43 \pm 1.25$ & $-26.61 \pm 1.78$ & $8.14 \pm 3.41$ & $9.9 \pm 5.8$ & $346.8 \pm 368.6$ & $28.8 \pm 3.0$ & $0.1 \pm 0.1$ \\
\hline \multicolumn{12}{|l|}{ Lianzhou Bay } \\
\hline Summer 2010 & 4 & $29.16 \pm 4.74$ & $1.14 \pm 0.27$ & $0.27 \pm 0.07$ & $4.97 \pm 0.67$ & $-21.46 \pm 0.47$ & $7.34 \pm 0.96$ & $3.7 \pm 2.2$ & $119.6 \pm 77.4$ & $25.7 \pm 0.2$ & $26.3 \pm 0.9$ \\
\hline Spring 2011 & 5 & $6.14 \pm 2.08$ & $5.99 \pm 2.74$ & $1.08 \pm 0.62$ & $8.14 \pm 2.53$ & $-23.86 \pm 0.25$ & $9.08 \pm 1.55$ & $4.1 \pm 2.9$ & $128.2 \pm 67.8$ & $21.6 \pm 1.6$ & $30.2 \pm 1.8$ \\
\hline Summer 2011 & 5 & $19.11 \pm 3.88$ & $2.73 \pm 0.38$ & $0.47 \pm 0.06$ & $6.81 \pm 0.33$ & $-21.17 \pm 0.33$ & $9.71 \pm 0.81$ & $6.5 \pm 1.2$ & $80.8 \pm 18.3$ & $26.1 \pm 0.6$ & $32.6 \pm 0.7$ \\
\hline \multicolumn{12}{|l|}{ Aquaculture } \\
\hline Summer 2010 & 10 & $73.62 \pm 30.15$ & $19.81 \pm 7.04$ & $3.39 \pm 0.99$ & $6.81 \pm 1.08$ & $-24.59 \pm 1.79$ & $4.33 \pm 1.81$ & $167.4 \pm 95.9$ & $73.1 \pm 65.3$ & $29.6 \pm 1.4$ & $8.1 \pm 3.9$ \\
\hline Spring 2011 & 9 & $26.02 \pm 12.37$ & $12.36 \pm 7.76$ & $1.96 \pm 1.10$ & $7.97 \pm 3.61$ & $-26.68 \pm 0.55$ & $6.33 \pm 0.23$ & $66.3 \pm 54.3$ & $75.8 \pm 66.1$ & $21.6 \pm 5.9$ & $11.7 \pm 5.1$ \\
\hline Summer 2011 & 7 & $40.80 \pm 19.10$ & $21.17 \pm 15.32$ & $4.40 \pm 3.47$ & $6.17 \pm 1.15$ & $-25.76 \pm 0.66$ & $5.97 \pm 3.12$ & $166.2 \pm 209.2$ & $94.0 \pm 52.6$ & $29.1 \pm 1.5$ & $4.6 \pm 4.2$ \\
\hline Huangzhu River & 1 & 2.02 & 12.32 & 2.54 & 5.65 & -29.34 & 2.12 & n.a. & n.a. & 18.5 & 0.9 \\
\hline Huangzhu Estuary & 2 & $24.44 \pm 4.38$ & $1.00 \pm 0.26$ & $0.24 \pm 0.06$ & $4.88 \pm 0.01$ & $-25.56 \pm 0.03$ & $3.97 \pm 0.03$ & n.a. & n.a. & $18.4 \pm 0.1$ & $25.7 \pm 1.3$ \\
\hline Shankou Mangrove & 7 & $27.56 \pm 7.05$ & $4.45 \pm 0.60$ & $0.74 \pm 0.16$ & $7.18 \pm 1.27$ & $-25.44 \pm 0.26$ & $2.41 \pm 0.60$ & $4.5 \pm 1.1$ & $276.3 \pm 56.8$ & $25.4 \pm 2.8$ & $18.8 \pm 3.1$ \\
\hline Shankou Marine & 7 & $12.51 \pm 4.59$ & $5.39 \pm 1.47$ & $0.87 \pm 0.34$ & $7.57 \pm 1.28$ & $-24.08 \pm 0.61$ & $6.78 \pm 0.50$ & $4.2 \pm 1.7$ & $171.7 \pm 80.1$ & $23.4 \pm 0.7$ & $32.1 \pm 0.2$ \\
\hline
\end{tabular}


a
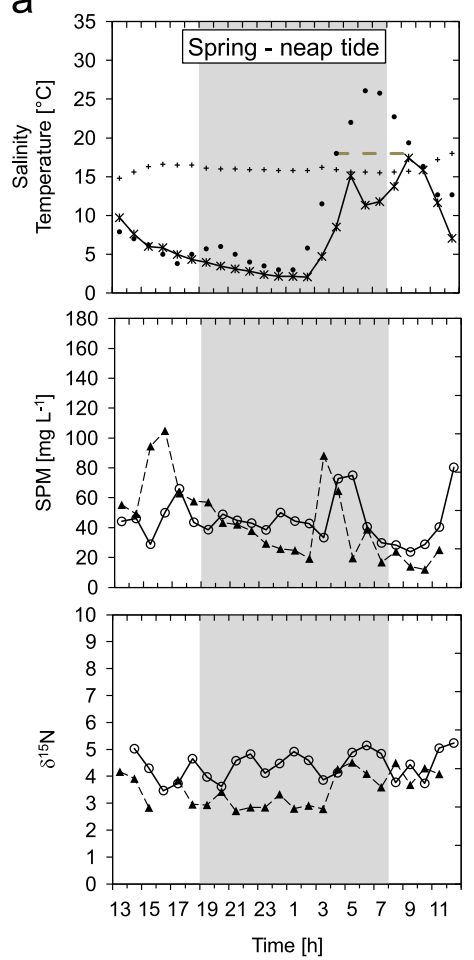

b
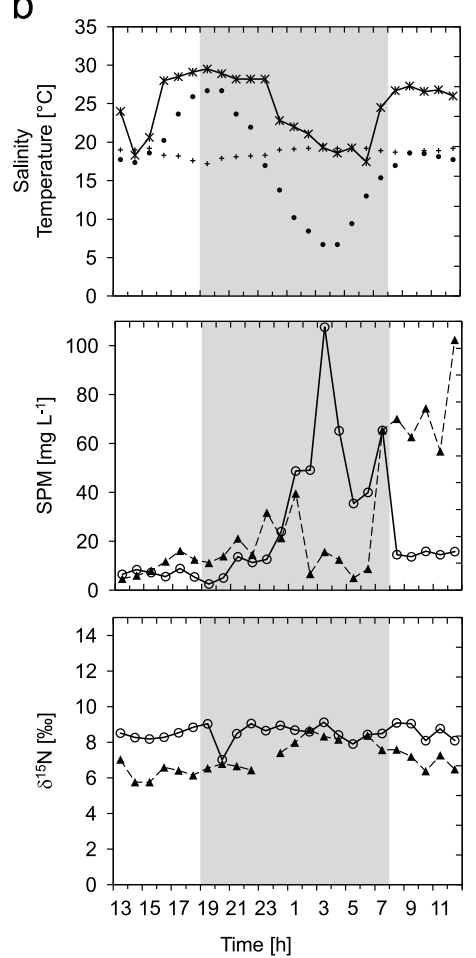
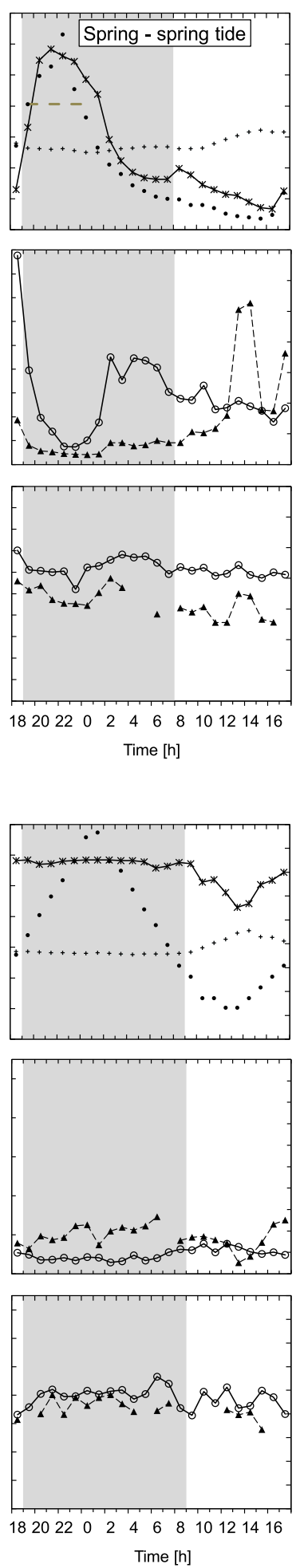
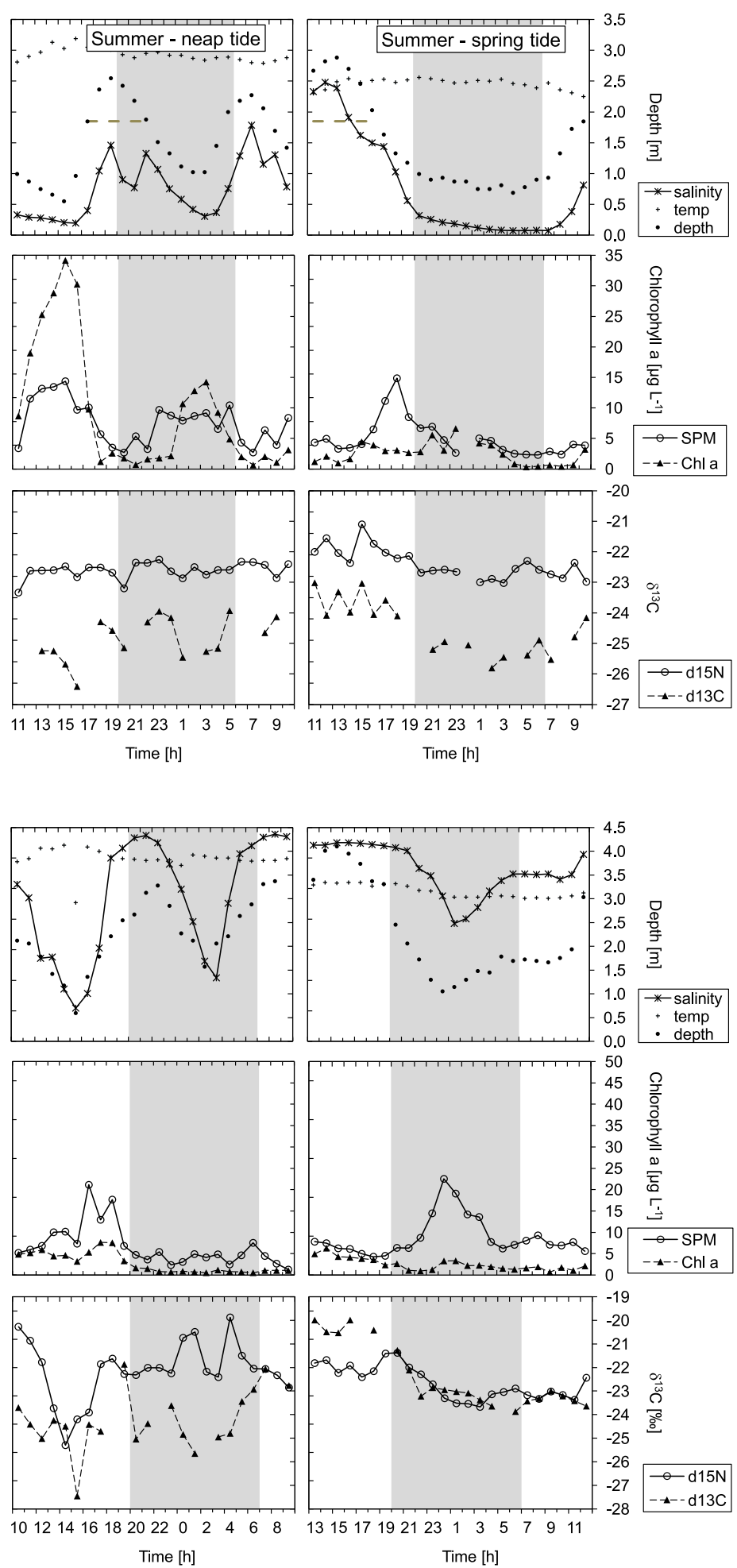

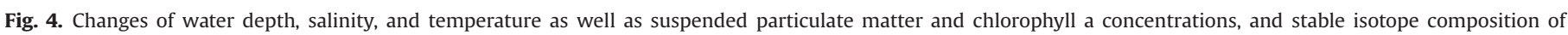

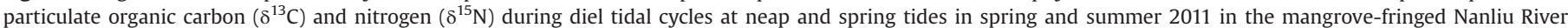

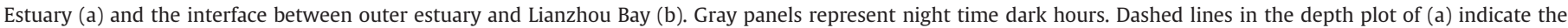
water depth necessary to inundate the mangrove sediment.

estuary during low water level and during high tidal current speed in the mangrove tidal station in spring 2011. The dominance of tidal samples caused intermediate salinity (7.3) and significantly lower temperature $\left(17.7^{\circ} \mathrm{C}\right)$ relative to other clusters. High POC/ CHLa (458.4) and C/N (8.68), as well as low \%POC (2.23\%) and \%N
(0.30\%), relative to clusters 3 and 4 , indicate that high SPM concentration (83.79) is caused by resuspension of sediments (Table 1). Cluster 6 (post-storm) contains all samples collected after the extreme rain caused by tropical storm Nesat $(n=5)$ and only one additional sample from mangrove tidal station in spring 2011. 
Table 2

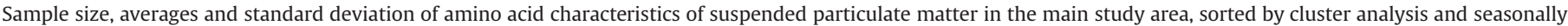

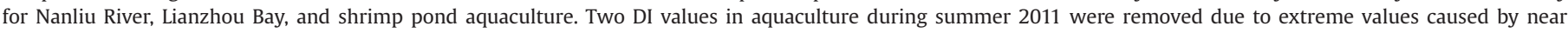
complete depletion of b-ALA and g-ABA.

\begin{tabular}{|c|c|c|c|c|c|c|c|c|c|c|}
\hline & $n$ & $\mathrm{AA}-\mathrm{C} \%$ & AA-N\% & AS-C\% & AS-N\% & $\mathrm{AA}\left[\mathrm{mg} \mathrm{g}^{-1}\right]$ & AS $\left[\mathrm{mg} \mathrm{g}^{-1}\right]$ & $\mathrm{AA} / \mathrm{AS}$ & DI & RI \\
\hline \multicolumn{11}{|l|}{ Clusters } \\
\hline Cluster 1 (marine) & 17 & $28.90 \pm 7.73$ & $52.02 \pm 12.13$ & $0.77 \pm 0.28$ & $0.90 \pm 0.42$ & $42.68 \pm 29.95$ & $2.68 \pm 0.89$ & $14.35 \pm 5.70$ & $0.69 \pm 0.23$ & $13.66 \pm 11.66$ \\
\hline Cluster 2 (outer estuary) & 10 & $24.83 \pm 5.39$ & $37.46 \pm 10.44$ & $1.51 \pm 0.54$ & $1.38 \pm 0.51$ & $9.87 \pm 5.81$ & $1.97 \pm 0.19$ & $4.91 \pm 2.59$ & $0.63 \pm 0.20$ & $5.61 \pm 2.89$ \\
\hline Cluster 3 (upriver) & 30 & $22.08 \pm 5.44$ & $42.44 \pm 12.63$ & $1.28 \pm 0.56$ & $1.50 \pm 0.74$ & $19.46 \pm 14.41$ & $2.43 \pm 0.36$ & $8.29 \pm 6.59$ & $0.46 \pm 0.17$ & $6.15 \pm 6.18$ \\
\hline Cluster 4 (river) & 16 & $17.93 \pm 3.77$ & $37.02 \pm 10.17$ & $1.63 \pm 0.29$ & $2.05 \pm 0.58$ & $11.69 \pm 6.31$ & $2.48 \pm 0.32$ & $4.55 \pm 1.69$ & $0.39 \pm 0.16$ & $2.69 \pm 1.33$ \\
\hline Cluster 5 (resuspension) & 3 & $18.29 \pm 2.72$ & $40.85 \pm 5.59$ & $1.99 \pm 0.25$ & $2.67 \pm 0.32$ & $9.03 \pm 2.14$ & $2.45 \pm 0.23$ & $3.65 \pm 0.57$ & $0.31 \pm 0.11$ & $2.00 \pm 0.27$ \\
\hline Cluster 6 (post-storm) & 3 & $16.91 \pm 1.38$ & $40.33 \pm 1.86$ & $1.02 \pm 0.31$ & $1.48 \pm 0.47$ & $7.78 \pm 1.05$ & $1.91 \pm 0.18$ & $4.08 \pm 0.39$ & $0.28 \pm 0.09$ & $2.51 \pm 0.49$ \\
\hline \multicolumn{11}{|l|}{ Nanliu River } \\
\hline Summer 2010 & 6 & $21.69 \pm 5.08$ & $37.90 \pm 9.29$ & $1.67 \pm 0.36$ & $1.76 \pm 0.38$ & $17.23 \pm 7.80$ & $1.91 \pm 0.51$ & $8.70 \pm 1.45$ & $0.53 \pm 0.22$ & $3.71 \pm 1.55$ \\
\hline Spring 2011 & 8 & $19.87 \pm 4.11$ & $39.47 \pm 14.83$ & $1.75 \pm 0.33$ & $2.10 \pm 0.77$ & $12.93 \pm 3.46$ & $1.68 \pm 0.31$ & $7.68 \pm 1.34$ & $0.35 \pm 0.14$ & $2.64 \pm 0.59$ \\
\hline Summer 2011 & 4 & $24.68 \pm 9.47$ & $45.88 \pm 7.66$ & $0.69 \pm 0.40$ & $0.87 \pm 0.59$ & $32.65 \pm 37.24$ & $0.81 \pm 0.32$ & $33.12 \pm 27.57$ & $0.43 \pm 0.27$ & $11.98 \pm 12.88$ \\
\hline \multicolumn{11}{|l|}{ Lianzhou Bay } \\
\hline Summer 2010 & 2 & $24.53 \pm 0.28$ & $31.53 \pm 1.52$ & $1.61 \pm 0.24$ & $1.29 \pm 0.12$ & $7.63 \pm 0.91$ & $0.75 \pm 0.01$ & $10.14 \pm 1.39$ & $0.83 \pm 0.02$ & $5.57 \pm 1.01$ \\
\hline Spring 2011 & 3 & $33.50 \pm 12.37$ & $70.29 \pm 3.35$ & $1.05 \pm 0.14$ & $1.44 \pm 0.39$ & $57.55 \pm 32.20$ & $2.69 \pm 0.91$ & $20.57 \pm 4.85$ & $0.75 \pm 0.09$ & $9.81 \pm 8.26$ \\
\hline Summer 2011 & 2 & $21.21 \pm 0.47$ & $39.21 \pm 1.31$ & $0.44 \pm 0.08$ & $0.50 \pm 0.12$ & $14.16 \pm 0.18$ & $0.45 \pm 0.10$ & $32.37 \pm 6.54$ & $0.47 \pm 0.10$ & $13.47 \pm 2.89$ \\
\hline \multicolumn{11}{|l|}{ Aquaculture } \\
\hline Summer 2010 & 9 & $29.87 \pm 5.83$ & $53.08 \pm 3.14$ & $1.18 \pm 0.22$ & $1.31 \pm 0.21$ & $115.12 \pm 31.76$ & $7.20 \pm 0.22$ & $16.73 \pm 2.97$ & $0.77 \pm 0.08$ & $7.48 \pm 1.81$ \\
\hline Spring 2011 & 6 & $32.49 \pm 6.48$ & $58.03 \pm 8.13$ & $2.03 \pm 0.96$ & $2.19 \pm 0.87$ & $76.63 \pm 48.04$ & $6.99 \pm 0.96$ & $12.76 \pm 6.64$ & $0.83 \pm 0.19$ & $14.44 \pm 8.59$ \\
\hline Summer 2011 & 3 & $22.36 \pm 13.26$ & $38.41 \pm 19.97$ & $0.51 \pm 0.28$ & $0.57 \pm 0.29$ & $136.04 \pm 110.91$ & $4.03 \pm 0.28$ & $29.68 \pm 15.30$ & $0.66 \pm 0.17$ & $3.24 \pm 0.0$ \\
\hline
\end{tabular}

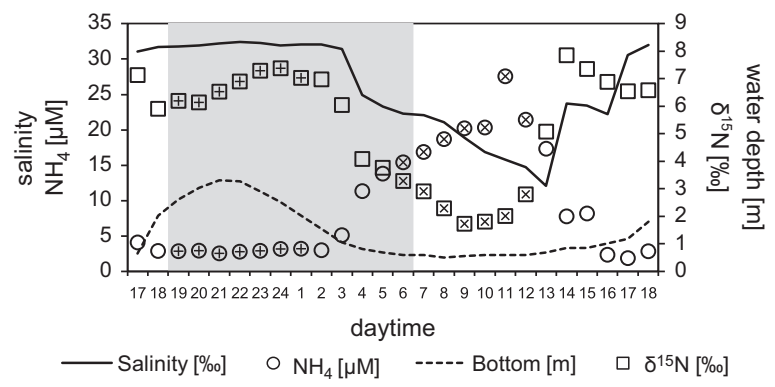

Fig. 5. Tidal variation of salinity and water depth as well as ammonium $\left(\mathrm{NH}_{4}\right)$ concentration and nitrogen stable isotope signature $\left(\delta^{15} \mathrm{~N}\right)$ of suspended particulate matter in the Shankou Mangrove system. Samples obtained during high tide and referred to in the text as marine are marked + , autochthonous mangrove samples obtained during low tide are marked $\times$. The gray area marks night time darkness.

It hence represents post-storm conditions with maximum SPM concentrations (171.29 $\mathrm{mg} \mathrm{L}^{-1}$ ), POC/CHLa (721.0) and C/N (12.82) ratios, and minimum average \% $\mathrm{POC}(2.00 \%)$ and $\% \mathrm{~N}(0.23 \%)$ (Table 1$)$.

Temperature is generally not different between clusters (with the exception of cluster 5 ) and large clusters (1,3, and 4) contain samples from all seasons (Table 3 ), indicating that seasonal differences in SPM concentrations and composition are not pronounced enough to influence clustering.

\subsection{Sediment and plant samples}

Organic carbon and total nitrogen content in sediments collected along the Nanliu Estuary ranged from $0.03-3.18$ and $0.01-0.26 \%$, respectively, and decreased from inner to outer estuary sediments (Fig. 3, Table 4). Sedimentary $\mathrm{C} / \mathrm{N}$ has a range of 5.43-14.89 and, contrary to SPM, showed a clear decrease from inner to outer estuary (Fig. 3, Table 4). Sedimentary $\delta^{13} \mathrm{C}$ and $\delta^{15} \mathrm{~N}$, ranging from -27.70 to $-20.49 \%$ and from 6.51 to $9.00 \%$, respectively, clearly increased along the continuum (Fig. 3, Table 4).

Mangrove sediments in the Nanliu Estuary varied in the range of $0.63-2.89 \%$ POC and $0.06-0.26 \% \mathrm{~N}$, but had higher average values than sediments of the surrounding estuary (Table 4). Sedimentary \%POC was similar in the mangroves of the Huangzhu Estuary (0.88-2.22\%) but considerably higher in Shankou
Mangrove (2.03-4.36\%) (Table 4). The C/N ratio was statistically similar between Huangzhu and Shankou Mangroves but significantly lower in the Nanliu Mangroves (ANOVA on Ranks, $P<0.05$ ). Mangrove sediment $\delta^{13} \mathrm{C}$ was significantly higher in the Nanliu Estuary than in other mangrove areas (Table 4; ANOVA on Ranks, $P<0.05)$. Significant differences between all systems existed for $\delta{ }^{15} \mathrm{~N}$ (one way ANOVA, $P<0.001$ ), which increased from 2.87$4.32 \%$ in Huangzhu to $6.33-7.11 \%$ in Shankou and 6.51-9.00\% in Nanliu Mangroves (averages \pm SD in Table 4).

Leaves of the two mangrove species did not have significantly different $\delta^{15} \mathrm{~N}$ or $\delta^{13} \mathrm{C}$ in either Nanliu or Huangzhu areas (Table 4). Mangroves of the Nanliu area revealed significantly higher leaf $\delta^{15} \mathrm{~N}$ than those of the Huangzhu area (two-way ANOVA, $P<0.001$ ). In both mangrove areas leaves had lower $\delta^{13} \mathrm{C}$ but higher $\mathrm{C} / \mathrm{N}$ than sediments (Table 4 ). Mangrove leaves are also carbon enriched compared to other plants, particularly rice, which had lowest C/N (Fig. 7, Table 4). Fresh eucalyptus leaves showed lowest $\delta^{13} \mathrm{C}$ and $\delta^{15} \mathrm{~N}$.

\section{Discussion}

\subsection{Concentrations and fluxes of suspended particulate matter}

The Nanliu River is characterized by intermediate concentrations of suspended particulate matter compared to other rivers (Bouillon et al., 2007a; Burns et al., 2008; Davies, 2004; Gao et al., 2007; Jennerjahn et al., 2008, 2004; Unger et al., 2013), including some major Chinese streams (Ni et al., 2008; Zhang et al., 1998), but concentrations are lower than in the Changjiang (Ittekkot and Zhang, 1989; Mao et al., 2010; Wang et al., 2012) and Huanghe (Ittekkot and Zhang, 1989; Mayer et al., 1998; Wang et al., 2012). The Red River, also debouching into the Beibu Gulf, carries considerably higher SPM concentrations of $>200 \mathrm{mg} \mathrm{L}^{-1}$ (Dang et al., 2010). In the Huangzhu River, upstream SPM concentration is very low (2.02 $\mathrm{mg} \mathrm{L}^{-1}$; Table 1 ), indicating low input from erosion on land. Organic carbon content of SPM (\%POC) in the Nanliu River is low compared to other small Chinese rivers (Gao et al., 2007; Unger et al., 2013), including the Huangzhu River (12.32\%; Table 1). POC concentrations are low in global comparison (Meybeck, 1982). Total nitrogen content in SPM $(\% \mathrm{~N})$ is lower than in other small tropical 


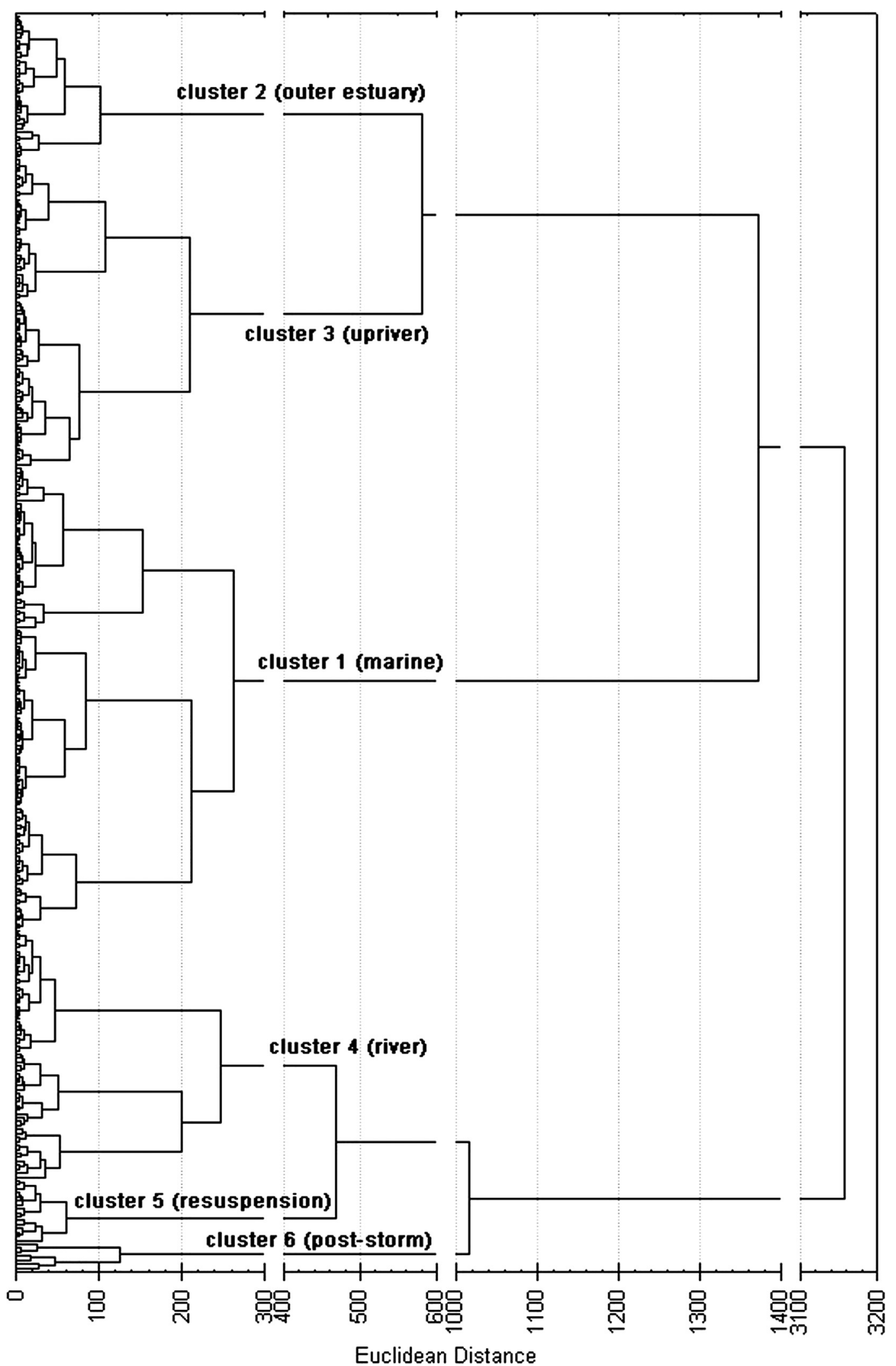

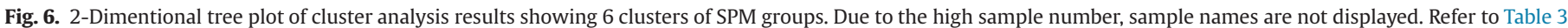
for contribution of samples to clusters.

and subtropical Chinese rivers (Unger et al., 2013; Huangzhu see Table 1), but still high compared to large Chinese rivers (Ittekkot and Zhang, 1989; Milliman et al., 1984; Wu et al., 2007; Zhang et al., 2007). The resulting particulate nitrogen to carbon ratio $(C / N)$ is generally close to the Redfield ratio (Tables 1 and 3), and thus lower than the average of world rivers (Meybeck, 1982).

SPM concentrations in the river reveal significant seasonal differences only if post-storm samples are excluded (Fig. 3). This is also 
Table 3

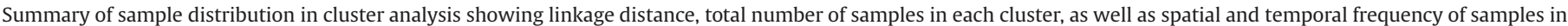
each cluster.

\begin{tabular}{|c|c|c|c|c|c|c|c|c|c|c|c|}
\hline \multirow[t]{2}{*}{ Cluster } & \multirow{2}{*}{$\begin{array}{l}\text { Linkage } \\
\text { distance }\end{array}$} & \multirow{2}{*}{$\begin{array}{l}\text { Total } \\
n\end{array}$} & \multicolumn{6}{|c|}{ Spatial frequency $[n]$} & \multicolumn{3}{|c|}{ Temporal frequency $[n]$} \\
\hline & & & River & $\begin{array}{l}\text { Inner } \\
\text { estuary }\end{array}$ & $\begin{array}{l}\text { Mangrove } \\
\text { tidal sampling }\end{array}$ & $\begin{array}{l}\text { Outer } \\
\text { estuary }\end{array}$ & $\begin{array}{l}\text { Outer tidal } \\
\text { sampling }\end{array}$ & Bay & $\begin{array}{l}\text { Summer } \\
2010\end{array}$ & $\begin{array}{l}\text { Spring } \\
2011\end{array}$ & $\begin{array}{l}\text { Summer } \\
2011\end{array}$ \\
\hline 1 (Marine) & 263 & 117 & 0 & 0 & 10 & 16 & 82 & 9 & 0 & 56 & 61 \\
\hline 2 (Outer estuary) & 103 & 36 & 0 & 0 & 10 & 9 & 12 & 5 & 10 & 12 & 14 \\
\hline 3 (Upriver) & 210 & 78 & 18 & 20 & 30 & 8 & 2 & 0 & 17 & 20 & 41 \\
\hline 4 (River) & 247 & 63 & 6 & 12 & 38 & 4 & 3 & 0 & 10 & 36 & 17 \\
\hline 5 (Resuspension) & 61 & 16 & 2 & 3 & 10 & 0 & 1 & 0 & 1 & 14 & 1 \\
\hline 6 (Post-storm) & 126 & 6 & 4 & 1 & 1 & 0 & 0 & 0 & 0 & 1 & 5 \\
\hline
\end{tabular}

Table 4

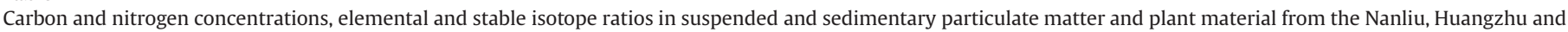
Shankou areas; values are pooled averages from all campaigns and standard deviations.

\begin{tabular}{|c|c|c|c|c|c|c|}
\hline Nanliu area & $n$ & \% POC & $\% \mathrm{~N}$ & $\delta^{13} \mathrm{C}[\% o]$ & $\delta^{15} \mathrm{~N}[\% o]$ & molar $\mathrm{C} / \mathrm{N}$ \\
\hline \multicolumn{7}{|l|}{ Nanliu area } \\
\hline River SPM & 30 & $3.64 \pm 1.92$ & $0.62 \pm 0.40$ & $-26.32 \pm 1.27$ & $7.54 \pm 2.20$ & $7.10 \pm 1.50$ \\
\hline Aquaculture SPM & 26 & $17.41 \pm 10.65$ & $3.15 \pm 2.21$ & $-25.14 \pm 1.63$ & $5.10 \pm 2.32$ & $7.06 \pm 2.41$ \\
\hline Bay SPM & 14 & $3.25 \pm 2.46$ & $0.63 \pm 0.50$ & $-22.21 \pm 1.32$ & $8.81 \pm 1.47$ & $6.76 \pm 1.96$ \\
\hline Aegiceras corniculatum & 26 & $49.55 \pm 1.69$ & $1.22 \pm 0.17$ & $-29.55 \pm 1.42$ & $7.82 \pm 1.39$ & $48.25 \pm 6.39$ \\
\hline Kandelia candel & 6 & $49.25 \pm 1.14$ & $1.23 \pm 0.16$ & $-28.83 \pm 0.61$ & $7.26 \pm 0.96$ & $47.18 \pm 5.66$ \\
\hline Eucalyptus & 7 & $52.41 \pm 2.26$ & $1.72 \pm 0.20$ & $-30.74 \pm 1.05$ & $2.14 \pm 1.52$ & $35.98 \pm 4.24$ \\
\hline Rice & 2 & $43.41 \pm 0.52$ & $4.18 \pm 0.65$ & $-29.33 \pm 0.23$ & $4.11 \pm 2.60$ & $12.27 \pm 2.05$ \\
\hline Marshgrass & 2 & $39.86 \pm 0.37$ & $1.34 \pm 0.22$ & $-12.56 \pm 0.14$ & $8.86 \pm 0.29$ & $35.03 \pm 5.50$ \\
\hline Inner estuary sediment & 16 & $1.18 \pm 0.75$ & $0.11 \pm 0.07$ & $-22.96 \pm 1.76$ & $6.97 \pm 1.12$ & $12.39 \pm 1.43$ \\
\hline River mouth sediment & 7 & $0.39 \pm 0.32$ & $0.05 \pm 0.04$ & $-21.24 \pm 1.29$ & $9.00 \pm 0.59$ & $9.46 \pm 1.51$ \\
\hline Outer estuary sediment & 8 & $0.10 \pm 0.03$ & $0.02 \pm 0.00$ & $-20.71 \pm 0.35$ & $10.04 \pm 0.50$ & $7.82 \pm 1.52$ \\
\hline Mangrove sediment & 36 & $1.58 \pm 0.52$ & $0.15 \pm 0.04$ & $-23.98 \pm 1.55$ & $7.70 \pm 0.51$ & $12.71 \pm 2.16$ \\
\hline \multicolumn{7}{|l|}{ Huangzhu area } \\
\hline River SPM & 1 & 12.32 & 2.54 & -29.34 & 2.12 & 5.65 \\
\hline Estuary SPM & 2 & $1.00 \pm 0.26$ & $0.24 \pm 0.06$ & $-25.56 \pm 0.03$ & $3.97 \pm 0.03$ & $4.88 \pm 0.01$ \\
\hline Aegiceras corniculatum & 11 & $49.01 \pm 1.87$ & $1.13 \pm 0.19$ & $-28.58 \pm 0.98$ & $4.61 \pm 1.18$ & $51.69 \pm 7.57$ \\
\hline Kandelia candel & 4 & $47.38 \pm 1.97$ & $1.18 \pm 0.09$ & $-28.56 \pm 0.64$ & $5.19 \pm 0.72$ & $46.96 \pm 4.13$ \\
\hline Mangrove sediment & 7 & $1.64 \pm 0.50$ & $0.09 \pm 0.02$ & $-26.50 \pm 0.46$ & $3.77 \pm 0.51$ & $21.23 \pm 4.63$ \\
\hline \multicolumn{7}{|l|}{ Shankou area } \\
\hline Marine SPM & 7 & $5.39 \pm 1.47$ & $0.87 \pm 0.34$ & $-24.08 \pm 0.61$ & $6.78 \pm 0.50$ & $7.57 \pm 1.28$ \\
\hline Mangrove SPM & 7 & $4.45 \pm 0.60$ & $0.74 \pm 0.16$ & $-25.44 \pm 0.26$ & $2.41 \pm 0.60$ & $7.18 \pm 1.27$ \\
\hline Mangrove sediment & 10 & $2.81 \pm 0.63$ & $0.19 \pm 0.04$ & $-25.32 \pm 0.67$ & $6.69 \pm 0.26$ & $17.25 \pm 2.48$ \\
\hline
\end{tabular}

reflected in the fact that riverine clusters 3 and 4 comprise samples from all seasons, suggesting that sub-seasonal meteorological events and tides dominate temporal variability. Tidal currents and wind forcing can induce resuspension of sediments (Guillén et al., 2006; Prins et al., 1997 and references therein; Smith et al., 2005). Resuspension is indicated by highest SPM concentrations during low tide in tidal samplings (Fig. 4) and weak correlation with salinity $\left(R^{2}=0.03-0.57\right)$ shows that tidal mixing of river and marine waters only explains $3-57 \%$ of the variability in SPM concentration. Thus, cluster 5 (resuspension) with second highest SPM concentrations is dominated by tidal station samples (Table 3 ) obtained during midebb and midflood tide, when erosion of bed sediments by tidal currents is strongest (see Middelburg and Herman, 2007). Extreme stormassociated rain caused a significant $(t$-test, $P<0.01) 10$-fold increase in SPM concentrations from $16.90 \mathrm{mg} \mathrm{L}^{-1}$ before to $164.75 \mathrm{mg} \mathrm{L}^{-1}$ after the event (Fig. 3), and post-storm samples dominate cluster 6 . Excessive rain enhances erosion of and runoff from agricultural surfaces, increasing inputs to Nanliu River and causing highest SPM concentrations. This event-driven variation contrasts the pronounced seasonal pattern of suspended matter concentrations of the Changjiang (Gao et al., 2012; Mao et al., 2010; Milliman et al., 1984) and other large rivers (e.g. Dang et al., 2010; Gupta et al., 1997; Ittekkot et al., 1985), but is similar to the flush driven variability found in other small Chinese rivers, where smaller catchment size facilitates rapid response to episodic events (Chen and Hong, 2011; Herbeck et al., 2011; Unger et al., 2013).

Using average concentrations (incl. extreme values from poststorm event) and annual water discharge, we calculated riverine fluxes of SPM, POC, and PN (Table 5). The SPM flux from the Nanliu River is two orders of magnitude lower than the long term average flux of $89 \times 10^{6} \mathrm{t} \mathrm{yr}^{-1}$ from the larger Red River (Dang et al., 2010). This low contribution of the Nanliu River to particle fluxes into the Beibu Gulf contrasts a disproportionately high contribution of this small river to dissolved matter fluxes (Kaiser et al. 2013). Due to high discharge of dissolved inorganic nitrogen (DIN) (Kaiser et al., 2013), the mass ratio of DIN to PN discharge is 8.7, and PN contributes only $7.5 \%$ to the total nitrogen flux in the Nanliu River. Similarly, particulate nitrogen contributes $<10 \%$ of total nitrogen in the Changjiang and its tributaries (Liu et al., 2003). The dominance of DIN over PN fluxes has been associated with strong human impact on nitrogen export (Seitzinger et al., 2002a), and is the typical result of high inorganic fertilizer inputs from agricultural hinterland. Thus, the low DIN/PN ratios of only 2.5 and 1.8 in the Huangzhu Estuary and Shankou Mangrove, respectively, are consistent with the assumed lower human impact.

Fluxes are about one order of magnitude higher during the high discharge seasons as compared to dry season (Table 5), resulting in significantly higher SPM concentrations in Lianzhou Bay during 


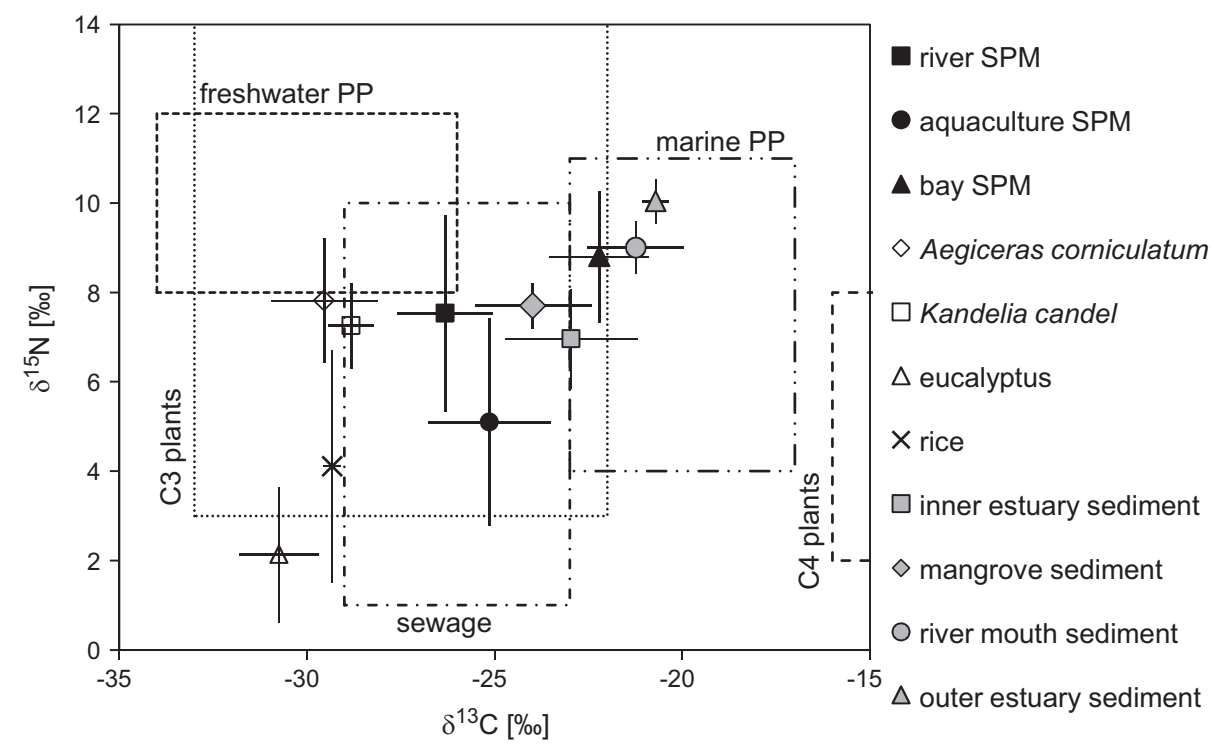

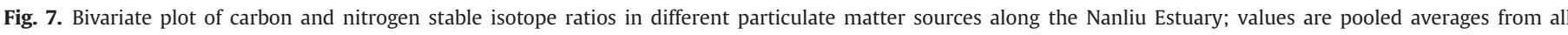

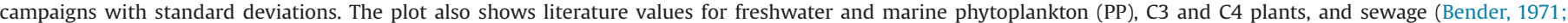
Bristow et al., 2012; Maksymowska et al., 2000 and references therein).

Table 5

Mass inputs of suspended particulate matter, carbon, and nitrogen into the Nanliu Estuary from the river and shrimp pond aquaculture. Yields are also given. Seasonal fluxes are calculated as the product of seasonal average concentrations and seasonal discharge as a percentage of annual discharge based on seasonal precipitation. Annual fluxes are the product of annual discharge and average concentrations of all samples. Wet season is from May to October, dry season from November to April; summer inputs from aquaculture refer to two mass inventories on the basis of two harvest-associated complete pond discharges, winter influence is negligible due to interrupted operations.

\begin{tabular}{lrrr}
\hline & SPM & POC & PN \\
\hline Nanliu River & & & \\
wet season 2010 flux [t] & 164,716 & 5,865 & 1,072 \\
Dry season 2010-2011 flux [t] & 19,719 & 575 & 89 \\
Wet season 2011 flux [t] & 361,745 & 8,350 & 1,236 \\
Average annual flux [t] & 284,623 & 7,968 & 1,259 \\
Average yield [kg ha ${ }^{-1} \mathrm{yr}^{-1}$ ] & 293 & 8 & 1 \\
Aquaculture & & & \\
Summer 2010 input [t] & 12,513 & 2,027 & 359 \\
Summer 2011 input [t] & 6,935 & 1,451 & 307 \\
Average yield [kg ha ${ }^{-1} \mathrm{yr}^{-1}$ ] & 1,532 & 269 & 51 \\
\hline
\end{tabular}

wet summer $(P<0.001$; Fig. 3, Table 1$)$. Due to the inclusion of post-storm samples in the wet season of 2011, calculated fluxes of SPM, POC, and PN, respectively, were 54, 30, and 13\% higher compared to 2010. Similarly, flood events can contribute $\sim 45 \%$ of the annual POC flux in the Pearl River (Sun et al., 2007). Significantly higher marine SPM concentration in summer 2010 than 2011 $(P=0.002)$ underline the importance of precipitation, which in the month before sampling was $394 \mathrm{~mm}$ in 2010 and $88 \mathrm{~mm}$ in 2011, respectively. Since precipitation-related flush events regularly affect many rivers, they need to be included in global land-ocean flux budgets in order to avoid biased estimates.

Though aquaculture yields in the Nanliu Estuary are high compared to yields from the Nanliu catchment, mass export of particulate matter is dominated by inputs from the much larger agricultural area (Table 4). The same has been found for dissolved nutrient export (Kaiser et al., 2013). The aquaculture influence on the Nanliu Estuary is thus masked by high river-borne particulate and dissolved inputs. Carbon fixation by in situ primary production in the outer estuary and bay averages $110 \mathrm{~g} \mathrm{OC} \mathrm{m}^{-2} \mathrm{yr}^{-1}$
(Lu et al., 1995), resulting in a total input of $26,070 \mathrm{t} \mathrm{yr}^{-1}$, more than double the amount provided by Nanliu River $\left(7968 \mathrm{t} \mathrm{yr}^{-1}\right.$, Table 5) and aquaculture (1739 $\mathrm{t} \mathrm{yr}^{-1}$ ) combined. River-borne fluxes are thus not the main source of nutrition to local coastal consumers, e.g. the large populations of filter-feeding bivalves (see Kaiser et al., 2013). However, marine primary production may be considered anthropogenically enhanced since the supporting dissolved nutrients derive dominantly from human inputs (Kaiser et al., 2013).

POC export fluxes from the Nanliu River are low to moderate in comparison to other rivers. High fluxes have been reported for small tropical and subtropical rivers, giving rise to the notion that these contribute over-proportionally to global particulate carbon transport from land to sea (e.g. Kao and Liu, 1997; Lyons et al., 2002). However, much of the data supporting this paradigm originates from steep, high-standing islands where much of the high carbon flux may be of fossil origin, being mobilized by soil erosion on steep terrain, often enhanced by deforestation (Kao and Liu, 1996). The Nanliu River has a comparatively gentle watershed and the transported POC primarily derives from in situ phytoplankton production with negligible contribution from terrestrial sources (see Section 4.2). Lower carbon fluxes can thus be expected from the Nanliu River. This study further shows that generalizations about river-to-sea matter transport are difficult and local scale studies are necessary for both local management and global (modeling) estimates.

\subsection{Composition and sources of suspended particulate matter}

The $\delta^{13} \mathrm{C}$ of SPM from the Nanliu (Fig. 7) and Huangzhu Rivers (Table 3) are within the range generally attributed to organic matter dominated by freshwater phytoplankton ( -34 to $-26 \%$; Bristow et al., 2012 and references therein). This overlaps with values of terrestrial C3 plants ( -33 to $-22 \%$; Bender, 1971) and sewage ( -28 to $-23 \%$; Andrews et al., 1998; Thornton and McManus, 1994). The molar C/N ratio however, is lower than that expected from terrestrial plants (16 to $>20$; Hedges and Oades, 1997; Hedges et al., 1988; Maksymowska et al., 2000) or their soils (usually > 12; Savoye et al., 2012), and that of sewage derived SPM ( $>11$; Andrews et al., 1998; Sweeney et al., 1980; Thornton and McManus, 1994), but is close to the ratio typical of autochthonous 
river OM (e.g. Bristow et al., 2012) and phytoplankton (Redfield et al., 1963). High chlorophyll $a$ concentrations in the river (up to $31 \mu \mathrm{g} \mathrm{L}^{-1}$ ) and generally low POC/CHLa values indicate high in situ phytoplankton production. Additionally, $\delta^{13} \mathrm{C}$ at the upper end of the range reported for riverine phytoplankton (Fig. 7) suggests some contribution of marine phytoplankton with higher $\delta^{13} \mathrm{C}$ ( -23 to $-17 \%$; see e.g. Bouillon et al., 2008) as the result of tidal upstream transport of coastal production. This isotopic and elemental composition shows that phytoplankton dominates the riverine OM pool. The high chlorophyll a values reflect freshwater eutrophication (Smith et al., 1999) caused by strong nutrient supply from agricultural runoff (Kaiser et al., 2013). This is consistent with observations in other watersheds, where high riverine chlorophyll $a$ concentrations correspond to high percentages of agricultural land-use (e.g. Hopkinson et al., 1998).

The $\delta^{13} \mathrm{C}$ of SPM shows an increase with salinity (Fig. 3), which is typically observed in many estuaries due to the increasing contribution of ${ }^{13} \mathrm{C}$ enriched marine phytoplankton (e.g. Hedges et al., 1997; Middelburg and Nieuwenhuize, 1998; Unger et al., 2013; Yu et al., 2010). Average $\delta^{13} \mathrm{C}$ of $-22.21 \%$ and $\mathrm{C} / \mathrm{N}$ of 6.76 show the dominance of marine phytoplankton OM in Lianzhou Bay (Table 4). Maximum DI, RI, and AA/AS, as well as lowest POC/ CHLa in cluster 1 and in the outer estuary and bay (Tables 1 and 2) show that in situ primary production is highest in coastal waters. This is driven by high nutrient supply from the Nanliu River (Kaiser et al., 2013), and results in higher chlorophyll $a$ concentrations than in eutrophic coastal waters of Hong Kong or the Pearl River estuary (Huang et al., 2003; Xu et al., 2012). Seasonal chlorophyll $a$ averages of 3.7-6.5 $\mu \mathrm{g} \mathrm{L}^{-1}$ show that Lianzhou Bay is eutrophic (Smith et al., 1999).

In aquaculture ponds, particulate $\delta^{13} \mathrm{C}$ between that of riverine and marine $\mathrm{OM}$ reflects the brackish water source of pond water with a mixture of plankton contained in estuarine source water (Fig. 7, Table 4). The average $\mathrm{C} / \mathrm{N}$ of 7.06 together with low POC/ CHLa values show that high CHLa concentrations (Table 1) are due to strong in situ phytoplankton production (see e.g. Cifuentes et al., 1988; Savoye et al., 2012), which is enhanced by fertilizers and provides the main OM source to consumers in ponds. Since OM in both the Nanliu River and its estuarine aquaculture derives mainly from phytoplankton production nourished by nutrients from fertilizer input (see Kaiser et al., 2013), export fluxes of POC and PN (Table 5) need to be regarded as anthropogenic inputs to coastal waters.

The low $\delta^{13} \mathrm{C}$ and high $\mathrm{C} / \mathrm{N}$ of mangroves and eucalyptus relative to SPM (Table 4), indicate that these higher plants contribute negligibly to particulate matter throughout the Nanliu Estuary. In combination with the low $\mathrm{C} / \mathrm{N}$ ratios in the Nanliu River, AA-C\% of $>19 \%$ in the river zone and Upriver cluster 3 (Table 2) confirms low contribution of AA-C poor plant and soil material. Low mangrove influence is due to the limited forest area and the rapid tidal export of intact leaves. The isotopic composition of Nanliu River OM also differs considerably from the signatures of C4 plants (Fig. 7), which are characterized by higher $\delta^{13} \mathrm{C}$ averaging around -14 to $-13 \%$ o (Bender, 1971; Smith and Epstein, 1971). As in other rivers (Hedges et al., 1986; Jennerjahn et al., 2004), the distinct $\delta^{13} \mathrm{C}$ signal of sugar cane, a C4 plant ( -13 to $-14 \%$, Andrews et al., 1998; Yu et al., 2010), is not reflected in river SPM, despite widespread sugar cane production in the watershed (Lagos et al., 2011). Similarly, riverine $\delta^{13} \mathrm{C}$ values suggest minor contribution of rice and other C3 plants to SPM (Table 4, Fig. 7). In agricultural areas of Guangxi Province, sugarcane and rice processing products are quantitatively removed from fields after harvest for further use (Fan et al., 2007; Li et al., 2001; Pimentel and Kounang, 1998; Zhu et al., 2007). The harvested aerial parts contribute most plant biomass and subaerial material may be rapidly decomposed, resulting in low accumulation of crop
OM in the soil (Wada et al., 1984). The introduction of crop-derived OM into the river is thus minimized. In many large rivers terrestrial soil-derived material dominates the particulate organic matter pool (Hedges et al., 1997), but low contribution and dominance of phytoplankton OM has been observed in other nutrient polluted estuaries with moderate SPM concentrations (e.g. Jennerjahn et al., 2004; Middelburg and Herman, 2007; Unger et al., 2013), potentially because in situ production is not limited by nutrient or light availability.

The $\delta^{15} \mathrm{~N}$ of SPM increases from the inner to the outer estuary (Fig. 3, Table 1) coinciding with rapidly decreasing DIN concentrations between these zones (Kaiser et al. 2013). $\delta^{15} \mathrm{~N}$ does not correlate with salinity during tidal samplings $\left(R^{2}=0.03-0.54\right.$, Fig. 4), suggesting a process related ${ }^{15} \mathrm{~N}$ enrichment rather than mixing of two distinct particle sources. In other estuaries, $\delta^{15} \mathrm{~N}$ enrichment has been attributed to preferential loss of ${ }^{14} \mathrm{~N}$ during OM degradation (see e.g. Jennerjahn et al., 2008). In the Nanliu Estuary this can be excluded because amino acid derived indicators reflect low degradation and increasing $\mathrm{OM}$ freshness off the river mouth. A dominant factor changing $\delta{ }^{15} \mathrm{~N}$ of estuarine SPM is uptake of residual ${ }^{15} \mathrm{NH}_{4}$ during high primary production at decreasing $\mathrm{NH}_{4}$ concentrations (Liu et al., 2007; Middelburg and Herman, 2007). As $\mathrm{NH}_{4}$ concentrations decrease to near-limiting levels, the possibility for discrimination against isotopically heavier molecules ceases and fractionation decreases. The consequently increasing uptake of residual heavy $\mathrm{NH}_{4}$ leads to conversion of $\delta^{15} \mathrm{~N}$ in SPM to that in the $\mathrm{NH}_{4}$ pool. The original $\mathrm{NH}_{4}$ pool can be expected to have high $\delta^{15} \mathrm{~N}$ due dominantly anthropogenic nitrogen sources (see Section 4.4), and to further increase along the river course due to the preferential removal of light ${ }^{14} \mathrm{NH}_{4}$ by primary production. In stream increase $\delta^{15} \mathrm{~N}$ in the $\mathrm{NH}_{4}$ pool may also be caused by ${ }^{14} \mathrm{NH}_{4}$ removal during nitrification, which is indicated in the Nanliu River and Estuary by high $\mathrm{NO}_{2}$ and dissolved concentrations (Kaiser et al., 2013).

Incorporation of ${ }^{15} \mathrm{NH}_{4}$ increases abruptly at concentrations $<20 \mu \mathrm{M}$ and $<30 \mu \mathrm{M}$ in the eutrophic Delaware and Danshui estuaries, respectively (Cifuentes et al., 1988; Liu et al., 2007). Threshold concentrations of DIN for increasing $\delta^{15} \mathrm{~N}$ have also been shown for estuarine macroalgae (Costanzo et al., 2003). In the Nanliu Estuary, enhanced incorporation of ${ }^{15} \mathrm{NH}_{4}$ occurs at concentrations $<10 \mu \mathrm{M}$, at which $\delta^{15} \mathrm{~N}$ of SPM increases to $6-14 \%$ (Fig. 8). Concentrations $<10 \mu \mathrm{M} \mathrm{NH}$ NH$_{4}$ occur throughout the system but dominate at salinities $>10$, i.e. in the outer estuary and bay (Kaiser et al., 2013), where different indices show highest primary productivity (Tables 1 and 2). Contrarily, there is no relationship between $\delta^{15} \mathrm{~N}$ of SPM and $\mathrm{NO}_{3}$ concentration. $\mathrm{NO}_{3}$ dominates the dissolved inorganic nitrogen pool throughout the system,

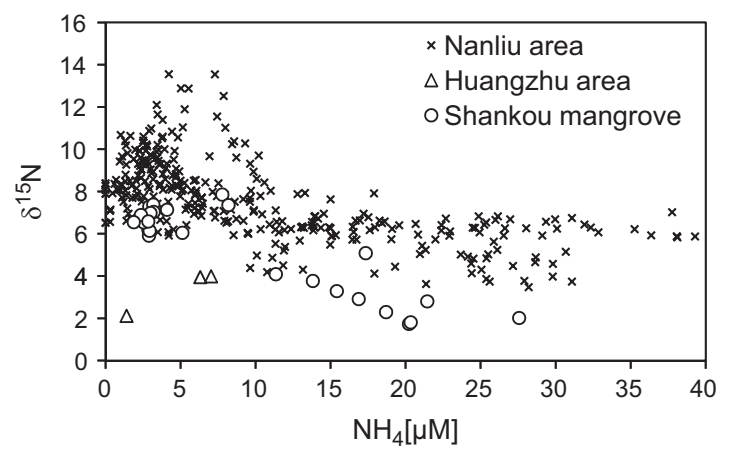

Fig. 8. Relationship between ammonium $\left(\mathrm{NH}_{4}\right)$ concentrations and nitrogen stable isotope signature $\left(\delta^{15} \mathrm{~N}\right)$ of suspended particulate matter from the entire river-baycontinuum. Ammonium values taken from Kaiser et al. (2013). 
contributing on average $94 \%$ in the river and $59 \%$ in the bay (see Kaiser et al., 2013). Concentrations of up to $209 \mu \mathrm{M}$ in the river and $32 \mu \mathrm{M}$ in the bay during the period of this study indicate that the availability of $\mathrm{NO}_{3}$ is too high to drive uptake of residual heavy $\mathrm{NO}_{3}$. Furthermore, conservative concentration decrease along the salinity gradient indicates no important $\mathrm{NO}_{3}$ uptake (see Kaiser et al., 2013). Conservative behavior of $\mathrm{NO}_{3}$ also indicates no significant addition through the nitrification of $\mathrm{NH}_{4}$, suggesting that this process has limited influence on $\delta^{15} \mathrm{~N}$ in the $\mathrm{NH}_{4}$ pool. The utilization of available $\mathrm{NH}_{4}$ influences the $\delta^{15} \mathrm{~N}$ of marine phytoplankton in these coastal waters. The increase of $\delta^{15} \mathrm{~N}$ due to uptake of heavy residual $\mathrm{NH}_{4}$ demonstrates the importance of the DIN source for the isotopic signature of particulate $\mathrm{OM}$ in this region. The increase in particulate $\delta^{15} \mathrm{~N}$ is low compared to other systems, where $\delta^{15} \mathrm{~N}$ may increase by up to 20\%o (Middelburg and Herman, 2007). Short residence time in Nanliu Estuary and Lianzhou Bay (Sun et al., 2014) probably limits $\delta^{15} \mathrm{~N}$ increase by shortening $\mathrm{N}$ processing and utilization times.

In aquaculture SPM, low $\delta^{15} \mathrm{~N}$ is due to the rapid direct uptake of applied synthetic fertilizer with low $\delta^{15} \mathrm{~N}(-3$ to $+3 \%$; Jennerjahn et al., 2008; Maksymowska et al., 2000; Panno et al., 2006), as particulate $\delta^{15} \mathrm{~N}$ is low in areas of direct excessive fertilizer application (see Kuramoto and Minagawa, 2001). This further shows that aquaculture production is sustained mainly by fertilizer enhanced phytoplankton biomass. In other aquaculture areas of south China the use of locally caught fish as aquaculture feed is the cause for higher $\delta{ }^{15} \mathrm{~N}$ of pond SPM as ${ }^{15} \mathrm{~N}$ accumulates in a food loop between local fish and particulate OM in pond effluents (Herbeck and Unger, 2013; Herbeck et al., 2012).

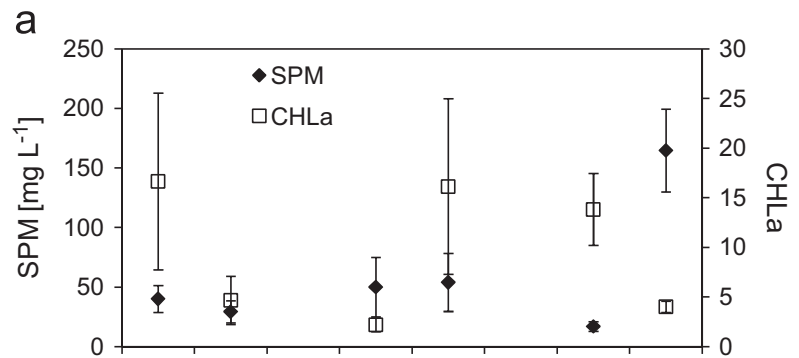

C

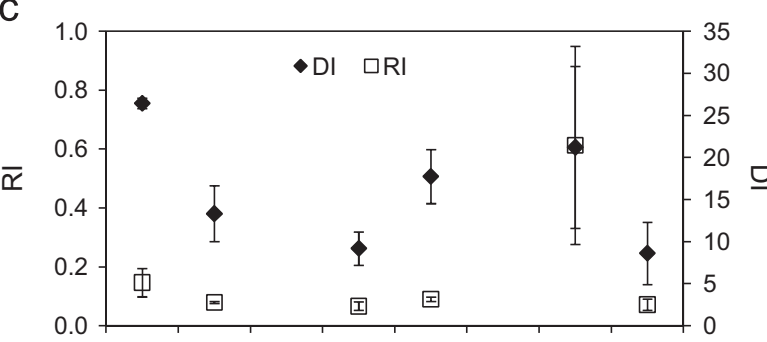

e

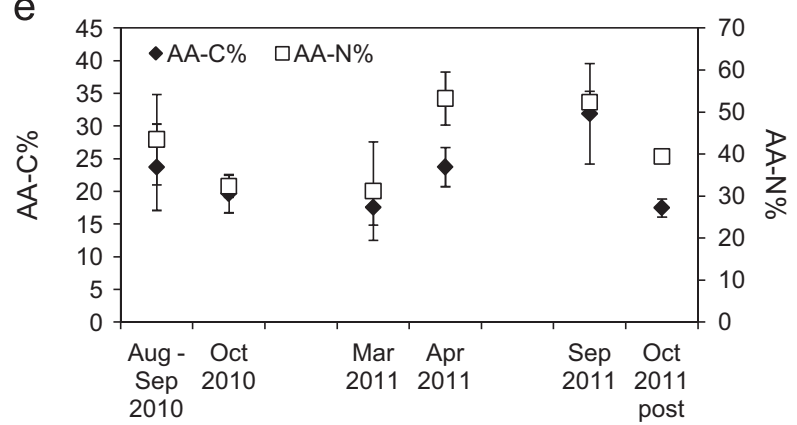

4.2.1. Variability in composition of suspended particulate matter

A clear seasonal difference is displayed by the gradient of $\delta^{13} \mathrm{C}$ between Nanliu River and Lianzhou Bay (Fig. 3). Estuarine gradients of OM composition have been suggested to depend on the dominant mixing mode, with steep gradients between clearly differentiated endmembers in river dominated estuaries and uniform values in tidal estuaries (Middelburg and Herman, 2007). In the Nanliu Estuary, in situ productivity is minimized by low temperature and light availability during early spring, blurring the distinct isotopic signatures of freshwater and marine phytoplankton. The concurrent low water discharge allows strong tidal mixing of riverine and marine organic matter, leading to the relatively uniform distribution of $\delta^{13} \mathrm{C}$ values along the continuum (Fig. 3). During summer, higher phytoplankton productivity throughout the system significantly lowers riverine $\delta^{13} \mathrm{C}$ (one-way ANOVA, $P<0.05$ ) and increases marine $\delta{ }^{13} \mathrm{C}$ (one-way ANOVA, $P<0.001$ ), enhancing the distinction between organic matter (signatures) (in the river and bay). Summer precipitation enhances water discharge, causing a relative dominance of riverine over tidal forcing in estuarine hydrography. Consequently, endmember signals are less strongly mixed than in spring and the estuarine gradient becomes steeper. This seasonal difference in estuarine mixing is confirmed by tidal samplings near Lianzhou Bay, where $\delta^{13} \mathrm{C}$ correlates positively with salinity in summer $\left(P<0.05, R^{2}>0.4\right)$ but not in spring. Stronger contribution of river-borne material in coastal water and homogeneous distribution of $\mathrm{OM}$ along the estuary during the low discharge season in winter has also been observed off the mouths of the Changjiang and Huanghe. In these large estuaries the contribution of autochthonous matter

b

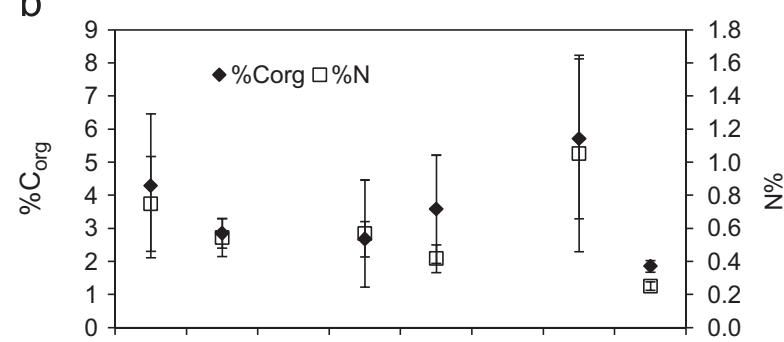

d

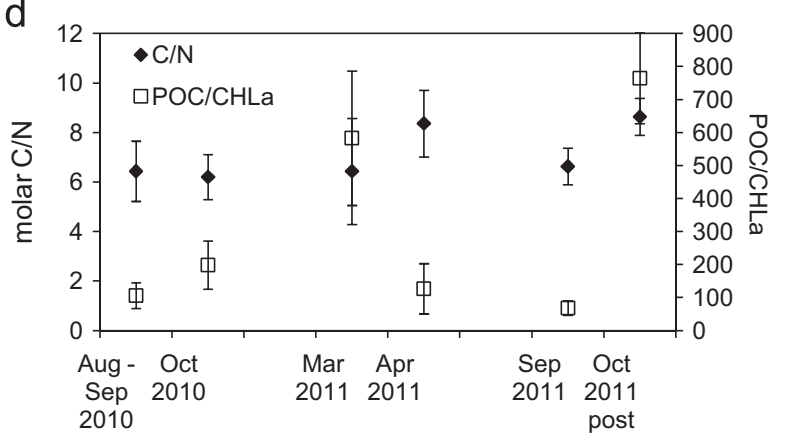

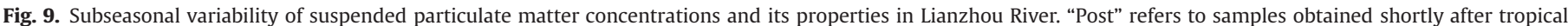
storm associated rains in October 2011. 
increased in summer, leading to a stronger separation between riverine and marine SPM signals (Cauwet and Mackenzie, 1993). Control of precipitation on the temporal and spatial variability of $\delta^{13} \mathrm{C}$ was also reported for the Pearl River estuary (Yu et al., 2010). These observations show that estuaries may not strictly be governed by one mode of mixing but alternate between river and tidal dominance, ultimately in response to precipitation strength.

In both Nanliu River and Lianzhou Bay values of $\delta^{13} \mathrm{C}$ were statistically similar during summer seasons (one-way ANOVA, $P>0.05$ ), indicating that freshwater and marine phytoplankton community composition is consistent (see e.g. Fry and Wainright, 1991) and that changes in composition is mainly due to endmember mixing. This is corroborated by seasonally similar $\mathrm{C} / \mathrm{N}$ ratios of riverine and marine SPM (one-way ANOVAs, $P>0.05$ ). The productivity of phytoplankton in the water, however, is subject to temporal variation. In Nanliu River low POC/CHLa of $<200$ together with high DI, RI, AA-C\%, AA-N\%, \%POC and \%N reflect fresh primary production during summer (Aug.-Sep. 2010, Fig. 9) and confirm phytoplankton as the dominant OM source (Cifuentes et al., 1988; Savoye et al., 2012). Decreasing OM freshness indicates that reduced productivity results in net degradation of riverine OM from autumn (October 2010) to early spring (March 2011), after which rapidly increasing productivity forms fresh POM in late spring (April) 2011. RI, AA-C\%, POC/CHLa, \%POC, and $\% \mathrm{~N}$ indicate highest riverine productivity during regular summer conditions (September) of 2011. The higher productivity compared to summer 2010 is probably caused by relatively long preceding warm, clear, and dry meteorological conditions (Fig. 2), providing favorable conditions for phytoplankton productivity, with minimum SPM concentrations ( $16.9 \mathrm{mg} \mathrm{L}^{-1}$, Fig. 9) due to low precipitation-driven erosion and land surface runoff (e.g. Pimentel and Kounang, 1998).

Freshness of riverine POM drastically decreases following extreme precipitation events. Concurrently, significantly elevated $\mathrm{C} / \mathrm{N}$ and $\delta^{13} \mathrm{C}$ in post-event compared to regular summer samples ( $t$-test, $P<0.001$; Figs. 3 and 9 ) reflect inputs of agricultural soil ( 8.9 and $-21.7 \%$, Yu et al., 2010). The consequently reduced light availability is accompanied by reduced nutrient concentrations (Kaiser et al., 2013) which results in decreased in situ primary production, mirrored in low CHLa concentration, \%POC, and \% (Figs. 3 and 9). Enhanced discharge may further reduce in situ productivity by decreasing residence time of phytoplankton in the river (see also Roegner et al., 2010). Extreme events cause rapid changes in riverine SPM composition that last at least several days. Considering the importance of episodic flushes for the magnitude of seasonal matter fluxes (see Section 4.1, Table 5), the runoff induced shift in POM composition in the Nanliu River makes terrestrial OM an important component of estuarine particle fluxes during the storm season. In Lianzhou Bay POC/CHLa is seasonally not different, further corroborating that POC is dominated by phytoplankton year round. The \%POC and \%N in these coastal waters are much higher in spring than summer (one-way ANOVA, $P>0.05)$. Significantly lower SPM concentrations compared to summer (one-way ANOVA, $P>0.001$ ) indicate that higher \%OM is due to lower dilution of marine productivity with river-borne mineral particles during the low discharge season. Average seasonal concentrations of SPM are negatively related to \%POC (Fig. 3, Table 1) and both parameters vary significantly between all seasons (one-way ANOVAs, $P<0.05$;). For individual samples SPM concentration and \% POC display a significant logarithmic relationship $\left(R^{2}=0.43\right)$ commonly observed in riverine and coastal systems and can be attributed to mineral particles diluting POC and inhibiting primary production (Ittekkot and Laane, 1991; Milliman et al., 1984; Zhang et al., 1998). This indicates that river derived inorganic SPM inputs substantially influence relative organic matter concentrations. Seasonal and subseasonal differences in riverine SPM fluxes (see Section 4.1) thus have significant influence on the temporal variability in coastal waters. Consequently, highest $\mathrm{AA}-\mathrm{C} \%$ and $\mathrm{AA}-\mathrm{N} \%$ in spring (one-way ANOVA, $P<0.05$; Table 2) indicate maximum freshness of marine OM during times of low riverine SPM fluxes (Table 5) due to high light and nutrient availability for primary production. Maximum productivity during spring blooms in Lianzhou Bay has been reported before (Chen, 1997; Committee of Annals of Chinese Estuaries, 1998).

Resuspension of sediments changes SPM composition by introducing degraded OM. This is shown by low \%POC and \%N but high $\mathrm{C} / \mathrm{N}$ and POC/CHLa, as well as low DI, RI, and AA/AS values in resuspension cluster 5 (Tables 1 and 2). Higher $\delta^{13} \mathrm{C}$ than in clusters 3 (upriver) and 4 (river) confirms the introduction of ${ }^{13} \mathrm{C}$ enriched sediments into the water column (compare Fig. 7). Cluster 5 is dominated by samples obtained during spring from the inner estuary tidal station (Table 3 ) at above average current velocity (data not shown). Tidal currents were significantly stronger in the inner than outer estuary $\left(0.6\right.$ and $0.2 \mathrm{~m} \mathrm{~s}^{-1}$, respectively; $t$-test, $P<0.05$ ). Resuspension measurably increased SPM concentrations at the tidal station during spring, concurrent with decreased values of \%POC, \%N (Fig. 3). River and inner estuary samples within cluster 5 were obtained during spring at the end of a period (10 days) of significantly higher daily average and maximum wind velocity than during summer (data from climate.usurf.usu.edu, not shown). Measureable influence of resuspension on estuarine particle concentrations and composition is thus restricted to the inner estuary during particularly strong tidal or wind action.

\subsection{Composition of sediments along the estuary}

Sediments show elevated $\delta^{13} \mathrm{C}$ compared to SPM but reflect the same gradient, increasing along the Nanliu Estuary (Fig. 3) and indicating an increasing contribution of marine $\mathrm{OM}$ in offshore direction (e.g. Jennerjahn et al., 2008). $\delta^{13} \mathrm{C}$ in sediments is generally higher than in the deposited OM source because of increasing contribution of bacteria in sediment OM compared to source OM (Ehleringer et al., 2000). The similar increase of $\delta^{13} \mathrm{C}$ from SPM to sediments along the estuary thus indicates that phytoplankton dominated SPM from the respective zone is the main source of POC originally deposited to sediments. The utilization of this POC by sedimentary bacteria increases $\delta^{13} \mathrm{C}$. Increased $\delta^{13} \mathrm{C}$ values may also result from deposition of terrestrial derived material, especially C4 plant matter. However, minor content of terrestrial material in SPM suggest also low contribution to sediment OM. Furthermore, low $\mathrm{C} / \mathrm{N}$ values in sediments, especially near the river mouth and in the outer estuary, corroborate phytoplankton dominated SPM as the main source of OM. Higher $\delta^{13} \mathrm{C}$ in sediments than SPM may also indicate ${ }^{13} \mathrm{C}$ enrichment during degradation of phytoplankton derived POM (e.g. Hamilton and Lewis, 1992). However, the negligible difference in $\mathrm{C} / \mathrm{N}$ and $\delta^{15} \mathrm{~N}$ between SPM and sediments (Fig. 3) suggests minor degradation of source OM. Relatively low degradation of this material may be due to rapid consumption of fresh material by benthic bivalves, which are abundant in all parts of the estuary and support a thriving economy.

Together with $\delta^{13} \mathrm{C}$, sedimentary $\delta^{15} \mathrm{~N}$ and $\mathrm{C} / \mathrm{N}$ exhibit a clear estuarine gradient though uniform sediment composition could be expected from tide dominated mixing (Grant and Middleton, 1990). Clear gradients between two distinct endmembers have been shown in other macro and micro tidal estuaries (e.g. Thornton and McManus, 1994; Unger et al., 2013) indicating that in small estuaries temporal integration in sediments compensates for tidal variability, irrespective of tidal regime. This temporal 
integration may render sediment OM a better parameter than SPM to distinguish signals of riverine and marine OM sources, especially in temporally restricted studies.

In Nanliu mangroves, the sediment organic carbon and total nitrogen content, ratio, and isotopic composition are similar to those found in other mangroves (e.g. Bouillon et al., 2007b; Jennerjahn and Ittekkot, 1997; Yu et al., 2010). Mangrove sedimentary $\mathrm{OM}$ is mostly derived from plant production (Bouillon et al., 2008). Values of $\delta^{13} \mathrm{C}$ are higher in sediments than leaves (Fig. 7, Table 4), a common phenomenon that has been ascribed to bacterial biomass, which has higher $\delta^{13} \mathrm{C}$ than the OM source it utilizes for growth (Bouillon et al., 2008). However, sedimentary $\mathrm{C} / \mathrm{N}$ varies between high values typical for higher plant leaves and low values of marine SPM (Table 4), suggesting considerable contribution from marine OM with also high $\delta^{13} \mathrm{C}$, imported from Lianzhou Bay during high tide. $\mathrm{C} / \mathrm{N}$ values of the two sources further converge during degradation (Ittekkot and Zhang, 1989) as they decrease in higher plants but increase in phytoplankton (Middelburg and Herman, 2007). The mangrove sediment OM source is thus dominated by mangrove litter, but contains considerable input of marine OM, and is colonized and utilized by sedimentary bacteria. The ${ }^{13} \mathrm{C}$ enrichment between leaves and sediments is highest in mangroves of the Nanliu Estuary compared to Huangzhu Estuary and Shankou while sedimentary $\mathrm{C} / \mathrm{N}$ is lowest (Table 4), indicating that import of marine OM is strongest in Nanliu mangroves.

Though mangrove derived OM may be exported to adjacent coastal areas (e.g. Jennerjahn and Ittekkot, 2002), $\delta^{13} \mathrm{C}$ and $\delta^{15} \mathrm{~N}$ of river mouth and outer estuarine sediments do not indicate mangrove OM deposition (Fig. 7, Table 4). Mangrove material also does not contribute to suspended or sedimentary matter in small estuaries of tropical south China (Unger et al., 2013),which is in part due to the recent decline in mangrove area in China (Bao et al., 2013; Li and Lee, 1997). It is noteworthy though, that the importance of mangrove material in adjacent systems is not yet conclusively delineated and there are indications that it may generally be low in some regions (Bouillon et al., 2008). In the Nanliu Estuary, mangroves may rather function as a sink for particulate carbon during sediment accretion associated with mangrove expansion (see Section 4.2).

\subsection{Tracing anthropogenic impact along the Guangxi coast}

Increasing anthropogenic $\mathrm{N}$ loading to and concentration in estuaries is frequently accompanied by an enrichment of ${ }^{15} \mathrm{~N}$ in SPM (Cole et al., 2004; McClelland and Valiela, 1998; Middelburg and Herman, 2007), rendering the $\delta^{15} \mathrm{~N}$ signature of PN a useful tracer of anthropogenic nitrogen pollution in aquatic and sedimentary systems (Costanzo et al., 2001; Heaton, 1986; McClelland and Valiela, 1998; McClelland et al., 1997; Savage, 2005). The ${ }^{15} \mathrm{~N}$ of suspended particulate nitrogen depends on the DIN source incorporated by PN forming phytoplankton. High DIN concentrations in the Nanliu system stem from agricultural and livestock inputs (Kaiser et al., 2013). The initially low $\delta^{15} \mathrm{~N}$ of synthetic fertilizer ( -3 to $+3 \%$; Jennerjahn et al., 2008; Maksymowska et al., 2000; Panno et al., 2006) may cause low $\delta^{15} \mathrm{~N}$ of $\mathrm{PN}$ in areas of direct application (Kuramoto and Minagawa, 2001), but values increase on agricultural watersheds to range between +5 to $+16 \%$ o (Kreitler, 1979; Panno et al., 2006). This enrichment is due to post-application nitrogen transformations, including denitrification and ammonia volatilization, that fractionate against ${ }^{15} \mathrm{~N}$ by favoring the loss of ${ }^{14} \mathrm{~N}$ (Anderson and Cabana, 2006; Hogberg, 1990). Livestock waste has similarly high $\delta^{15} \mathrm{~N}(+10$ to $+25 \%$, Anderson and Cabana, 2006; Panno et al., 2006). The $\delta^{15} \mathrm{~N}$ of mainly anthropogenic DIN in the Nanliu River can thus be assumed to be high $(>8 \%$ ). Uptake of heavy nitrogen by phytoplankton (Cifuentes et al., 1988; Harrington et al., 1998; Mariotti et al., 1984; Middelburg and Nieuwenhuize, 1998) translates the agriculture or livestock derived signal into high $\delta^{15} \mathrm{~N}$ of SPM.

In the Huangzhu and Shankou systems low DIN concentrations (8.4-12.2 and 3.9-33.2 $\mu \mathrm{M}$, respectively) and minor agricultural activity (pers. obs.) indicate low anthropogenic nutrient pollution, which suggests low $\delta^{15} \mathrm{~N}$ of DIN. Land-derived nitrogen loading to the Shankou Mangrove is low because there is no riverine influence. Reflecting low direct anthropogenic influence, $\delta^{15} \mathrm{~N}$ of autochthonous SPM is low in the Huangzhu River and Shankou Mangrove compared to the Nanliu River (Table 4). $\mathrm{NH}_{4}$ concentrations in the Huangzhu area are consistently $<8 \mu \mathrm{M}$ (compare Fig. 8). At such low concentrations $\delta^{15} \mathrm{~N}$ generally increases, indicating lower fractionation of the $\mathrm{NH}_{4}$ pool due to decreasing availability (see Section 4.2, Fig. 8). The nevertheless low $\delta^{15} \mathrm{~N}-\mathrm{SPM}$ of $<4 \%$ in the Huangzhu area thus reflects an isotopically lighter $\mathrm{NH}_{4}$ pool than in the anthropogenically affected Nanliu Estuary. In the Shankou Mangrove tidal station $\delta^{15} \mathrm{~N}$ correlates linearly with $\mathrm{NH}_{4}\left(R^{2}=0.82\right)$ but not with $\mathrm{NO}_{3}$ concentrations. Similar to the Nanliu area, $\delta{ }^{15} \mathrm{~N}$ values $\geq 6 \%$ o do not occur at $\mathrm{NH}_{4}$ concentrations $>10 \mu \mathrm{M}$ but dominate at $<10 \mu \mathrm{M}$ (Fig. 5). However, significant correlation of both $\delta^{15} \mathrm{~N}\left(P<0.001 ; R^{2}=0.528\right)$ and $\mathrm{NH}_{4}\left(P<0.001 ; R^{2}=0.799\right)$ with salinity, and significant differences between low and high tide ( $t$-test, $P>0.001$, Fig. 6 ) suggest this to be due to mixing of a mangrove derived source with high $\mathrm{NH}_{4}$ concentrations and low $\delta{ }^{15} \mathrm{~N}-\mathrm{SPM}$ signature and a marine source with low $\mathrm{NH}_{4}$ concentrations but higher $\delta^{15} \mathrm{~N}-\mathrm{SPM}$ signature. Though, given the potential influence of degradation and fractionation, differences in particulate $\delta^{15} \mathrm{~N}$ must generally be large for effective source separation (Robinson, 2001), along the Guangxi coast between-system differences are significant. High $\delta^{15} \mathrm{~N}$ is thus a good tracer for the strong anthropogenic impact in the Nanliu system, while low values reflect relatively undisturbed condition in the Huangzhu and Shankou systems.

In Shankou, increased $\delta^{15} \mathrm{~N}$ signals in allochthonous marine compared to autochthonous mangrove SPM suggest that pollution is introduced with the tide from remote sources along the coast. The traditional concept of long shore currents in the northern Beibu Gulf, with seasonally alternating transport directions, has been contested in a recent modeling study indicating year round westward currents (Wu et al., 2008). Nevertheless, freshwater from polluted rivers, including the Nanliu, disperses along the entire northern Beibu Gulf coast (Chen et al., 2011). While several streams debouch into Yinglou Bay north of Shankou, these are small seasonal rivers without discharge during the dry season. Their minor relevance for hydrology in the region is reflected in the absence of hydrological stations (GMRC, unpublished observations). Another potential source of tidally imported pollution is Jiuzhou River east of Shankou. High DIN concentrations have been measured at the mouth but are locally restricted (Gan, Guangzhou Marine Geological Survey, personal communication). Unlike the Nanliu River basin, land-use in the catchment has no particular economic importance (www.nanning.gov.cn, 2010), indicating comparatively low human impact. This suggests the larger Nanliu River to be the most important source of coastal pollution in the area. The open morphology and lack of river runoff facilitate import of pollution into Shankou Mangrove.

The relatively small increase of $\delta^{15} \mathrm{~N}$ along the Huangzhu Estuary suggests considerably lower import of anthropogenic material. This is unexpected given the year round presence of diluted river water in adjacent coastal areas (Chen et al., 2011) and the close proximity to an important industrial harbor (www. nanning.gov.cn, 2010). Probably, the enclosed morphology of Pearl Bay with its narrow $(3 \mathrm{~km}$ ) opening limits intrusion of water from remote sources, and river runoff reduces the effective tidal inflow of water from the Beibu Gulf. 
The gradient of anthropogenic impact between the systems is also reflected in mangrove sediments, which are most ${ }^{15} \mathrm{~N}$ enriched in the Nanliu Estuary and have higher $\delta^{15} \mathrm{~N}$ values in Shankou than Pearl Bay (Table 4). Increasing $\delta^{15} \mathrm{~N}$ in sediments adjacent to mangrove forest are indicative of increasing contribution of anthropogenic nitrogen (Bao et al., 2013) and influence from human impacted rivers (Kuramoto and Minagawa, 2001). Mangrove leaves from the Nanliu are also ${ }^{15} \mathrm{~N}$ enriched relative to Huangzhu mangroves (Table 4). Variations in leaf $\delta^{15} \mathrm{~N}$ largely depend on the sources of nitrogen accumulated by the plant (Bouillon et al., 2008; Robinson, 2001) and values increase with exposure to anthropogenic nitrogen (Costanzo et al., 2004; Kuramoto and Minagawa, 2001; McClelland and Valiela, 1998). Due to their slower growth and immobility higher plants have stronger temporal integration than phytoplankton and their $\delta^{15} \mathrm{~N}$ represents environmental conditions over a longer time scale for a fixed location (e.g. Costanzo et al., 2003). Costanzo et al. (2003) found no seasonal difference in mangrove leaf $\delta^{15} \mathrm{~N}$ despite variable anthropogenic N input. Similarly, sediments may integrate temporal variability of inputs from different sources. Thus, the differences observed in leaves and sediments confirm that the gradient of pollution suggested by $\delta^{15} \mathrm{~N}$ in SPM is not due to temporally different sampling, but persists permanently.

The results suggest that polluted areas influence remote sites, depending not only on large scale current patterns but also on local morphological and hydrological conditions. The observed long distance transfer of polluted material is an important factor for coastal conservation efforts and has to be considered if nature reserves like the Shankou Mangrove are to be successfully protected.

\section{Summary and conclusion}

A multi-parameter approach including elemental, isotopic, and amino acid composition of particulate matter was successfully used to delineate sources and transformation processes of OM in a macrotidal estuary under multiple human and natural influences.

Throughout the Nanliu system suspended particulate organic matter is dominated by autochthonous primary production and there is little evidence for direct terrestrial OM inputs. Consequently, sediment $\mathrm{OM}$ along the estuary seems to be composed mainly of phytoplankton detritus, except in mangroves, where litter detritus contributes importantly to relatively high organic matter concentrations. The high phytoplankton fraction in POM has important implications for benthic and costal pelagic food webs, as it is more bioavailable than terrestrial soil OM, providing a high quality food source for locally important commercial species (e.g. clams). Concentration and composition of SPM display strong subseasonal variability, especially in response to productivity and precipitation regimes. Extreme precipitation increases terrestrial runoff, introducing agricultural soil into the river and estuary. Seasonal precipitation patterns cause alternation in estuarine mixing with river dominance during high discharge season but strong tidal mixing during dry month. The annual riverine export far exceeds that of aquaculture effluents, despite high yields from ponds.

Multiple driving factors and temporal and spatial variability show that coastal fluxes and dynamics cannot be generalized and regional scale studies are important puzzle pieces for an accurate picture of land-ocean-connectivity.

High riverine and marine productivity is fueled by anthropogenic nutrient inputs and reflects eutrophic conditions. Though considerably smaller than dissolved loads, particulate matter loads and fluxes thus add to the export of anthropogenic nutrients from highly disturbed watersheds, and should be included in assessments of human impacts on land-ocean-fluxes. The study has shown that these inputs are dispersed along the coast depending on current patterns as well as on local scale topography and hydrology. This has implications for protection, restoration, and conservation of remote nature reserves. Dispersal can be traced by $\delta^{15} \mathrm{~N}$, which may serve as a tool for monitoring changing human influence during future coastal development in the region.

\section{Acknowledgements}

This project was carried out in cooperation with colleagues from the Guangxi Mangrove Research Center in Beihai, Guangxi, who provided samples from Pearl Bay and Shankou areas. For help during fieldwork in the Nanliu area we thank Sun Ting, Christina Staschock, Julia Lange, and Pauliana Agustin. Great lab work assistance was provided by Dorothee Dasbach. Thanks to Huayang Gan of the Guangzhou Marine Geological Survey for providing the base map of Guangxi's coast. The German Federal Ministry for Education and Science (BMBF; project no.: 03F 0607 B) financed this research.

\section{Appendix A. Supporting information}

Supplementary data associated with this article can be found in the online version at http://dx.doi.org/10.1016/j.csr.2014.04.006.

\section{References}

Abreu, P.C., Costa, C.S.B., Bemvenuti, C., Odebrecht, C., Graneli, W., Anesio, A.M., 2006 Eutrophication processes and trophic interactions in a shallow estuary: preliminary results based on stable isotope analysis $\left(\delta^{13} \mathrm{C}\right.$ and $\left.\delta^{15} \mathrm{~N}\right)$. Estuaries Coasts: J. Estuarine Res. Fed. 29, 277-285, http://dx.doi.org/10.1007/BF02781996.

Anderson, C., Cabana, G., 2006. Does $\delta^{15} \mathrm{~N}$ in river food webs reflect the intensity and origin of $\mathrm{N}$ loads from the watershed? Sci. Total Environ. 367, 968-978, http://dx.doi.org/10.1016/i.scitotenv.2006.01.029.

Andrews, J.E., Greenaway, A.M., Dennis, P.F., 1998. Combined carbon isotope and $\mathrm{C} / \mathrm{N}$ ratios as indicators of source and fate of organic matter in a poorly flushed, tropical Estuary: Hunts Bay, Kingston Harbour, Jamaica. Estuarine Coastal Shelf Sci. 46, 743-756, http://dx.doi.org/10.1006/ecss.1997.0305.

Bao, H., Wu, Y., Unger, D., Du, J., Herbeck, L.S., Zhang, J., 2013. Impact of the conversion of mangroves into aquaculture ponds on the sedimentary organic matter composition in a tidal flat estuary (Hainan Island, China). Cont. Shelf Res. 57, 82-91, http://dx.doi.org/10.1016/j.csr.2012.06.016.

Bender, M.M., 1971. Variations in the ${ }^{13} \mathrm{C} /{ }^{12} \mathrm{C}$ ratios of plants in relation to the pathway of photosynthetic carbon dioxide fixation. Phytochemistry 10, 1239-1244, http: //dx.doi.org/10.1016/S0031-9422(00)84324-1.

Benner, R., Kaiser, K., 2003. Abundance of amino sugars and peptidoglycan in marine particulate and dissolved organic matter. Limnol. Oceanogr. 48, $118-128$.

Beusen, A.H.W., Dekkers, A.L.M., Bouwman, A.F., Ludwig, W., Harrison, J., 2005 Estimation of global river transport of sediments and associated particulate C, N, and P. Global Biogeochem. Cycles 19, GB4S05, http://dx.doi.org/10.1029/ 2005 gb002453.

Bouillon, S., Connolly, R.M., Lee, S.Y., 2008. Organic matter exchange and cycling in mangrove ecosystems: recent insights from stable isotope studies. J. Sea Res. $59,44-58$.

Bouillon, S., Dehairs, F., Schiettecatte, L.S., Borges, A.V., 2007a. Biogeochemistry of the Tana estuary and delta (northern Kenya). Limnol. Oceanogr., 46-59.

Bouillon, S., Dehairs, F., Velimirov, B., Abril, G., Borges, A.V., 2007b. Dynamics of organic and inorganic carbon across contiguous mangrove and seagrass systems (Gazi Bay, Kenya). J. Geophys. Res. 112, G02018, http://dx.doi.org/ 10.1029/2006JG000325.

Bristow, L.A., Jickells, T.D., Weston, K., Marca-Bell, A., Parker, R., Andrews, J.E., 2012. Tracing estuarine organic matter sources into the southern North Sea using $C$ and $\mathrm{N}$ isotopic signatures. Biogeochemistry, 1-14.

Burns, K.A., Brunskill, G., Brinkman, D., Zagorskis, I., 2008. Organic carbon and nutrient fluxes to the coastal zone from the Sepik River outflow. Cont. Shelf Res. 28, 283-301, http://dx.doi.org/10.1016/j.csr.2007.08.004.

Cai, W.-J., Dai, M., Wang, Y., Zhai, W., Huang, T., Chen, S., Zhang, F., Chen, Z., Wang, Z., 2004. The biogeochemistry of inorganic carbon and nutrients in the Pearl River estuary and the adjacent Northern South China Sea. Cont. Shelf Res. 24 1301-1319, http://dx.doi.org/10.1016/j.csr.2004.04.005.

Cauwet, G., Mackenzie, F.T., 1993. Carbon inputs and distribution in estuaries of turbid rivers: the Yang Tze and Yellow rivers (China). Mar. Chem. 43, 235-246, http://dx.doi.org/10.1016/0304-4203(93)90229-H. 
Chen, B. (Ed.), 1997. Marine Environmental Characteristics of the Nanliu Delta. Guangxi. Ocean Press, Beijing, PRC.

Chen, B., Qiu, S.F., Liang, W., 2007. Analysis on formation of underwater delta shoal and tidal groove of Lianzhou Gulf Nanliujiang River. J. Guangxi Acad. Sci. 23, 102-105.

Chen, N., Hong, H., 2011. Nitrogen export by surface runoff from a small agricultural watershed in southeast China: seasonal pattern and primary mechanism. Biogeochemistry 106, 311-321, http://dx.doi.org/10.1007/s10533-010-9514-6.

Chen, S., Li, Y., Hu, J., Zheng, A., Huang, L., Lin, Y., 2011. Multiparameter cluster analysis of seasonal variation of water masses in the eastern Beibu Gulf. J. Oceanogr., 67.

Cifuentes, L.A., Fogel, M.L., Pennock, J.R., Sharp, J.H., 1989. Biogeochemical factors that influence the stable nitrogen isotope ratio of dissolved ammonium in the Delaware Estuary. Geochim. Cosmochim. Acta 53, 2713-2721, http://dx.doi.org/ 10.1016/0016-7037(89)90142-7.

Cifuentes, L.A., Sharp, J.H., Fogel, M.L., 1988. Stable carbon and nitrogen isotope biogeochemistry in the Delaware Estuary. Limnol. Oceanogr. 33, 1102-1115, http://dx.doi.org/10.2307/2837243.

Cole, M.L., Valiela, I., Kroeger, K.D., Tomasky, G.L., Cebrian, J., Wigand, C., McKinney, R.A., Grady, S.P., Carvalho da Silva, M.H., 2004. Assessment of a $\delta^{15} \mathrm{~N}$ isotopic method to indicate anthropogenic eutrophication in aquatic ecosystems. J. Environ. Qual. 33, 124-132.

Committee of Annals of Chinese Estuaries, 1998. Annals of Chinese Estuaries. Ocean Press, Beijing, PRC.

Costanzo, S.D., O'Donohue, M.J., Dennison, W.C., 2003. Assessing the seasonal influence of sewage and agricultural nutrient inputs in a subtropical river estuary. Estuaries 26, 857-865, http://dx.doi.org/10.1007/BF02803344.

Costanzo, S.D., O’Donohue, M.J., Dennison, W.C., 2004. Assessing the influence and distribution of shrimp pond effluent in a tidal mangrove creek in north-east Australia. Mar. Pollut. Bull. 48, 514-525, http://dx.doi.org/10.1016/j.marpolbul. 2003.09.006.

Costanzo, S.D., O’Donohue, M.J., Dennison, W.C., Loneragan, N.R., Thomas, M., 2001. A new approach for detecting and mapping sewage impacts. Mar. Pollut. Bull. 42, 149-156, http://dx.doi.org/10.1016/S0025-326X(00)00125-9.

Costanzo, S.D., Udy, J., Longstaff, B., Jones, A., 2005. Using nitrogen stable isotope ratios $\left(\delta^{15} \mathrm{~N}\right)$ of macroalgae to determine the effectiveness of sewage upgrades: changes in the extent of sewage plumes over four years in Moreton Bay, Australia. Mar. Pollut. Bull. 51, 212-217, http://dx.doi.org/10.1016/j.marpolbul.2004.10.018.

Cowie, G.L., Hedges, J.I., 1992. Sources and reactivities of amino acids in a coastal marine environment. Limnol. Oceanogr. 37, 703-724, http://dx.doi.org/10.2307 /2837933.

Dai, J., Zhang, X., Wang, D., Guo, C., Fang, R., Wang, X., 2011. Water quality change of Nanliu River in Guangxi Beibu Gulf Economic Zone. In: RSETE (Ed.), International Conference on Remote Sensing, Environment and Transportation Engineering (RSETE), 2011, pp. 5629-5632.

Dang, T.H., Coynel, A., Orange, D., Blanc, G., Etcheber, H., Le, L.A., 2010. Long-term monitoring (1960-2008) of the river-sediment transport in the Red River Watershed (Vietnam): temporal variability and dam-reservoir impact. Sci. Total Environ. 408, 4654-4664, http://dx.doi.org/10.1016/j.scitotenv.2010.07.007.

Dauwe, B., Middelburg, J.J., 1998. Amino acids and hexosamines as indicators of organic matter degradation state in North Sea sediments. Limnol. Oceanogr. 43, $782-798$.

Dauwe, B., Middelburg, J.J., Herman, P.M.J., Heip, C.H.R., 1999. Linking diagenetic alteration of amino acids and bulk organic matter reactivity. Limnol. Oceanogr. 44, 1809-1814, http://dx doi.org/10.4319/lo.1999.44.71809.

Davies, P., 2004. Nutrient processes and chlorophyll in the estuaries and plume of the Gulf of Papua. Cont. Shelf Res. 24, 2317-2341, http://dx.doi.org/10.1016/j. csr.2004.07.012.

Ehleringer, J.R., Buchmann, N., Flanagan, L.B., 2000. Carbon isotope ratios in belowground carbon cycle processes. Ecol. Appl. 10, 412-422, http://dx.doi. org/10.1890/1051-0761(2000)010[0412:CIRIBC]2.0.CO;2.

Fan, S., Freedman, B., Gao, J., 2007. Potential environmental benefits from increased use of bioenergy in China. Environ. Manage. 40, 504-515, http://dx.doi.org/ 10.1007/s00267-006-0116-y.

French, C., 2010. Spectrophotometric Determination of Corrected and Uncorrected Chlorophyll a and Pheophytin.

Fry, B., Wainright, S.C., 1991. Diatom sources of ${ }^{13} \mathrm{C}$-rich carbon in marine food webs. Mar. Ecol. Prog. Ser. 76, 149-157.

Gao, L., Li, D., Zhang, Y., 2012. Nutrients and particulate organic matter discharged by the Changjiang (Yangtze River): seasonal variations and temporal trends. J. Geophys. Res. Biogeosci. 117, 1-16, http://dx.doi.org/10.1029/2012JG001952.

Gao, Q., Tao, Z., Yao, G., Ding, J., Liu, Z., Liu, K., 2007. Elemental and isotopic signatures of particulate organic carbon in the Zengjiang River, southern China. Hydrol. Processes 21, 1318-1327, http://dx.doi.org/10.1002/hyp.6358.

Granger, J., Sigman, D.M., Lehmann, M.F., Tortell, P.D., 2008. Nitrogen and oxygen isotope fractionation during dissimilatory nitrate reduction by denitrifying bacteria. Limnol. Oceanogr. 53, 2533.

Granger, J., Sigman, D.M., Needoba, J.A., Harrison, P.J., 2004. Coupled nitrogen and oxygen isotope fractionation of nitrate during assimilation by cultures of marine phytoplankton. Limnol. Oceanogr. 49, 1763-1773.

Granger, J., Sigman, D.M., Rohde, M.M., Maldonado, M.T., Tortell, P.D., 2010. N and O isotope effects during nitrate assimilation by unicellular prokaryotic and eukaryotic plankton cultures. Geochim. Cosmochim. Acta 74, 1030-1040, http://dx.doi.org/10.1016/j.gca.2009.10.044.
Grant, A., Middleton, R., 1990. An assessment of metal contamination of sediments in the humber estuary, U.K. Estuarine Coastal Shelf Sci. 31, 71-85, http://dx.doi. org/10.1016/0272-7714(90)90029-Q.

Guillén, J., Bourrin, F., Palanques, A., Durrieu de Madron, X., Puig, P., Buscail, R., 2006. Sediment dynamics during wet and dry storm events on the Têt inner shelf (SW Gulf of Lions). Mar. Geol. 234, 129-142, http://dx.doi.org/10.1016/j. margeo.2006.09.018.

Gupta, L.P., Kawahata, H., 2000. Amino acid and hexosamine composition and flux of sinking particulate matter in the equatorial Pacific at $175^{\circ}$ E longitude. Deep Sea Res. Part I 47, 1937-1960, http://dx.doi.org/10.1016/S0967-0637(00)00009-1.

Gupta, L.P., Subramanian, V., Ittekkot, V., 1997. Biogeochemistry of particulate organic matter transported by the Godavari River, India. Biogeochemistry 38, $103-128$

Haake, B., Ittekkot, V., Ramaswamy, V., Nair, R.., Honjo, S., 1992. Fluxes of amino acids and hexosamines to the deep Arabian Sea. Mar. Chem. 40, 291-314, http: //dx.doi.org/10.1016/0304-4203(92)90028-9.

Hamilton, S.., Lewis Jr., W.., 1992. Stable carbon and nitrogen isotopes in algae and detritus from the Orinoco River floodplain, Venezuela. Geochim. Cosmochim. Acta 56, 4237-4246, http://dx.doi.org/10.1016/0016-7037(92)90264-J.

Harrington, R.R., Kennedy, B.P., Chamberlain, C.P., Blum, J.D., Folt, C.L., 1998. 15 N enrichment in agricultural catchments: field patterns and applications to tracking Atlantic salmon (Salmo salar). Chem. Geol. 147, 281-294, http://dx. doi.org/10.1016/S0009-2541(98)00018-7.

Heaton, T.H.E., 1986. Isotopic studies of nitrogen pollution in the hydrosphere and atmosphere: a review. Chem. Geol. 59, 87-102.

Hedges, J.I., Clark, W.A., Cowie, G.L., 1988. Organic matter sources to the water column and surficial sediments of a marine bay. Limnol. Oceanogr. 33, 1116-1136, http //dx.doi.org/10.2307/2837244.

Hedges, J.I., Clark, W.A., Quay, P.D., Richey, J.E., Devol, A.H., Santos, U., de, M., 1986 Compositions and fluxes of particulate organic material in the Amazon River Limnol. Oceanogr. 31, 717-738.

Hedges, J.I., Keil, R.G., Benner, R., 1997. What happens to terrestrial organic matter in the ocean? Org. Geochem. 27, 195-212, http://dx.doi.org/10.1016/S0146 6380(97)00066-1.

Hedges, J.I., Oades, J.M., 1997. Comparative organic geochemistries of soils and marine sediments. Org. Geochem. 27, 319-361, http://dx.doi.org/10.1016/ S0146-6380(97)00056-9.

Herbeck, L.S., Unger, D., 2013. Pond aquaculture effluents traced along back-reef waters by standard water quality parameters, $\delta^{15} \mathrm{~N}$ in suspended matter and phytoplankton bioassays. Mar. Ecol. Prog. Ser. 478, 71-86, http://dx.doi.org/ 10.3354/meps10170.

Herbeck, L.S., Unger, D., Krumme, U., Liu, S.M., Jennerjahn, T.C., 2011. Typhooninduced precipitation impact on nutrient and suspended matter dynamics of a tropical estuary affected by human activities in Hainan, China. Estuarine Coastal Shelf Sci. 93, 375-388, http://dx.doi.org/10.1016/j.ecss.2011.05.004.

Herbeck, L.S., Unger, D., Wu, Y., Jennerjahn, T.C., 2012. Effluent, nutrient and organic matter export from shrimp and fish ponds causing eutrophication in coasta and back-reef waters of NE Hainan, tropical China. Cont. Shelf Res. http://dx doi.org/10.1016/j.csr.2012.05.006.

Hodgkiss, I., Ho, K., 1997. Are changes in N:P ratios in coastal waters the key to increased red tide blooms? Hydrobiologia 352, 141-147, http://dx.doi.org 10.1023/a:1003046516964.

Hogberg, P., 1990. Forests losing large quantities of nitrogen have elevated $15 \mathrm{~N}: 14 \mathrm{~N}$ ratios. Oecologia 84, 229-231, http://dx.doi.org/10.1007/BF00318276.

Hopkinson, C.S., Buffam, I., Hobbie, J., Vallino, J., Perdue, M., Eversmeyer, B., Prahl, F. Covert, J., Hodson, R., Moran, M.A., et al., 1998. Terrestrial inputs of organic matter to coastal ecosystems: an intercomparison of chemical characteristics and bioavailability. Biogeochemistry 43, 211-234.

Huang, X.P., Huang, L.M., Yue, W.Z., 2003. The characteristics of nutrients and eutrophication in the Pearl River estuary, South China. Mar. Pollut. Bull. 47, 30-36.

Ittekkot, V. Laane, R.W.P.M. 1991. Fate of riverine particulate organic matter. In: Degens, E.T., Kempe, S., Richey, J.E. (Eds.), Biogeochemistry of Major World Rivers., SCOPE. Wiley, Chichester, pp. 233-243.

Ittekkot, V., Safiullah, S., Mycke, B., Seifert, R., 1985. Seasonal variability and geochemical significance of organic matter in the River Ganges, Bangladesh. Nature 317, 800-802, http://dx.doi.org/10.1038/317800a0.

Ittekkot, V., Zhang, S., 1989. Pattern of particulate nitrogen transport in world rivers. Global Biogeochem. Cycles 3, 383-391, http://dx.doi.org/10.1029/ GB003i004p00383.

Jeffrey, S.W., Humphrey, G.F., 1975. New spectrophotometric equations for determining chlorophylls a, b, c1 and c2 in higher plants, algae and natura phytoplankton. Biochem. Physiol. Pflanzen 167, 4

Jennerjahn, T., Ittekkot, V., 1997. Organic matter in sediments in the mangrove areas and adjacent continental margins of Brazil.1. Amino acids and hexosamines. Oceanolica Acta 20, 359-369.

Jennerjahn, T., Ittekkot, V., 2002. Relevance of mangroves for the production and deposition of organic matter along tropical continental margins. Naturwisenschaften 89, 23-30.

Jennerjahn, T., Soman, K., Ittekkot, V., Nordhaus, I., Sooraj, S., Priya, R., Lahajnar, N., 2008. Effect of land use on the biogeochemistry of dissolved nutrients and suspended and sedimentary organic matter in the tropical Kallada River and Ashtamudi estuary, Kerala, India. Biogeochemistry 90, 29-47.

Jennerjahn, T.C., Ittekkot, V., 1999. Changes in organic matter from surface waters to continental slope sediments off the São Francisco River, eastern Brazil. Mar. Geol. 161, 129-140, http://dx.doi.org/10.1016/S0025-3227(99)00045-6. 
Jennerjahn, T.C., Ittekkot, V., Klopper, S., Adi, S., Purwo Nugroho, S., Sudiana, N., Yusmal, A., Prihartanto, Gaye-Haake, B., 2004. Biogeochemistry of a tropical river affected by human activities in its catchment: Brantas River estuary and coastal waters of Madura Strait, Java, Indonesia. Estuarine Coastal Shelf Sci. 60, 503-514.

Jiang, L.M., Chen, B., Qiu, S.F., 2008. The Relationship of Silt Transportation and Ocean Dynamical Condition in Delta of Lianzhou Bay. J. Guangxi Acad. Sci. 24, 25-28.

Kaiser, D., Unger, D., Qiu, G., Zhou, H., Gan, H., 2013. Natural and human influences on nutrient transport through a small subtropical Chinese estuary. Sci. Total Environ. 450-451, 92-107, http://dx.doi.org/10.1016/j.scitotenv.2013.01.096.

Kao, S.J., Liu, K.K., 1997. Fluxes of dissolved and nonfossil particulate organic carbon from an Oceania small river (Lanyang Hsi) in Taiwan. Biogeochemistry 39, 255-269, http://dx.doi.org/10.1023/A:1005864605382.

Kao, S.-J., Liu, K.-K., 1996. Particulate organic carbon export from a subtropical Mountainous River (Lanyang Hsi) in Taiwan. Limnol. Oceanogr. 41, 1749-1757, http://dx.doi.org/10.2307/2838659.

Kendall, C., Caldwell, E.A., 1998. Fundamentals of isotope geochemistry. In: Kenda C., McDonnell, J.J. (Eds.), Isotope Tracers in Catchment Hydrology. Elsevier Science B.V., Amsterdam, pp. 51-86.

Kennedy, P., Kennedy, H., Papadimitriou, S., 2005. The effect of acidification on the determination of organic carbon, total nitrogen and their stable isotopic composition in algae and marine sediment. Rapid Commun. Mass Spectrom. 19, 1063-1068, http://dx.doi.org/10.1002/rcm.1889.

Kreitler, C.W., 1979. Nitrogen-isotope ratio studies of soils and groundwater nitrate from alluvial fan aquifers in Texas. J. Hydrol. 42, 147-170, http://dx.doi.org 10.1016/0022-1694(79)90011-8.

Kuramoto, T., Minagawa, M., 2001. Stable carbon and nitrogen isotopic characterization of organic matter in a Mangrove ecosystem on the Southwestern Coast of Thailand. J. Oceanogr. 57, 421-431, http://dx.doi.org/10.1023/A:1021232132755.

Lagos, J.E., Jiang, J., Sindelar, S., 2011. Peoples Republic of China Sugar Annual 2011 (Required Report-Public Distribution no. CH11019). Global Agricultural Information Network (GAIN), Beijing, PRC.

Lehmann, M.F., Bernasconi, S.M., Barbieri, A., McKenzie, J.A., 2002. Preservation of organic matter and alteration of its carbon and nitrogen isotope composition during simulated and in situ early sedimentary diagenesis. Geochim. Cosmochim. Acta 66, 3573-3584, http://dx.doi.org/10.1016/S0016-7037(02)00968-7.

Li, J., Zhuang, X., DeLaquil, P., Larson, E.D., 2001. Biomass energy in China and its potential. Nat. Gas $938(2-1)$

Li, M.S., Lee, S.Y., 1997. Mangroves of China: a brief review. Forest Ecol. Manag. 96, 241-259.

Liu, K.-K., Kao, S.-J., Wen, L.-S., Chen, K.-L., 2007. Carbon and nitrogen isotopic compositions of particulate organic matter and biogeochemical processes in the eutrophic Danshuei Estuary in northern Taiwan. Sci. Total Environ. 382 103-120, http://dx.doi.org/10.1016/j.scitotenv.2007.04.019.

Liu, S.M., Zhang, J., Chen, H.T., Wu, Y., Xiong, H., Zhang, Z.F., 2003. Nutrients in the Changjiang and its tributaries. Biogeochemistry 62, 1-18.

Lorenzen, C.J., 1967. Determination of chlorophyll and pheo-pigments: spectrophotometric equations. Limnol. Oceanogr. 12, 343-346.

Lu, R., Xia, B., Mao, X., 1995. A study on the primary productivity of Lianzhou Bay waters of Guangxi Province. J. Oceanogr. Huanghai Bohai Seas 13, 52-60.

Lyons, W.B., Nezat, C.A., Carey, A.E., Hicks, D.M., 2002. Organic carbon fluxes to the ocean from high-standing islands. Geology 30, 443-446, http://dx.doi.org/ 10.1130/0091-7613(2002)030<0443:OCFTTO > 2.0.CO;2.

Maksymowska, D., Richard, P., Piekarek-Jankowska, H., Riera, P., 2000. Chemical and isotopic composition of the organic matter sources in the Gulf of Gdansk (Southern Baltic Sea). Estuarine Coastal Shelf Sci. 51, 585-598, http://dx.doi. org/10.1006/ecss.2000.0701.

Mao, C., Chen, J., Yuan, X., Yang, Z., Balsam, W., Ji, J., 2010. Seasonal variation in the mineralogy of the suspended particulate matter of the Lower Changjiang River at Nanjing, China. Clays Clay Miner. 58, 691-706, http://dx.doi.org/10.1346/ CCMN.2010.0580508.

Mariotti, A., Lancelot, C., Billen, G., 1984. Natural isotopic composition of nitrogen as a tracer of origin for suspended organic matter in the Scheldt estuary. Geochim. Cosmochim. Acta 48, 549-555, http://dx.doi.org/10.1016/0016-7037 (84)90283-7.

Mayer, L.M., Keil, R.G., Macko, S.A., Joye, S.B., Ruttenberg, K.C., Aller, R.C., 1998 Importance of suspended particulates in riverine delivery of bioavailable nitrogen to coastal zones. Global Biogeochem. Cycles 12, 573.

McClelland, J.W., Valiela, I., 1998. Linking nitrogen in estuarine producers to landderived sources. Limnol. Oceanogr. 43, 577-585.

McClelland, J.W., Valiela, I., Michener, R.H., 1997. Nitrogen-stable isotope signatures in estuarine food webs: a record of increasing urbanization in coastal watersheds. Limnol. Oceanogr. 42, 930-937.

Meybeck, M., 1982. Carbon, nitrogen, and phosphorus transport by world rivers. Am. J. Sci. 282, 401-450, http://dx.doi.org/10.2475/ajs.282.4.401.

Meybeck, M., Vorosmarty, C., 1999. Global transfer of carbon by rivers. Global Change Newslett. 37, 18-19.

Middelburg, J.J., Herman, P.M.J., 2007. Organic matter processing in tidal estuaries. Mar. Chem. 106, 127-147, http://dx.doi.org/10.1016/j.marchem.2006.02.007.

Middelburg, J.J., Nieuwenhuize, J., 1998. Carbon and nitrogen stable isotopes in suspended matter and sediments from the Schelde Estuary. Mar. Chem. 60, 217-225, http://dx.doi.org/10.1016/S0304-4203(97)00104-7.

Milliman, J.D., Qinchun, X., Zuosheng, Y., 1984. Transfer of particulate organic carbon and nitrogen from the Yangtze River to the ocean. Am. J. Sci. 284 824-834, http://dx.doi.org/10.2475/ajs.284.7.824.
Milliman, J.D., Syvitski, J.P., 1992. Geomorphic/tectonic control of sediment discharge to the ocean: the importance of small mountainous rivers. J. Geol., 525-544.

Müller, P.J., Suess, E., Ungerer, C.A., 1986. Amino acids and amino sugars of surface particulate and sediment trap material from waters of the Scotia sea. Deep Sea Res. Part A 33, 819-838, http://dx.doi.org/10.1016/0198-0149(86)90090-7.

Ni, H.-G., Lu, F.-H., Luo, X.-L., Tian, H.-Y., Zeng, E.Y., 2008. Riverine inputs of total organic carbon and suspended particulate matter from the Pearl River Delta to the coastal ocean off South China. Mar. Pollut. Bull. 56, 1150-1157, http://dx.doi. org/10.1016/j.marpolbul.2008.02.030

Panno, S.V., Hackley, K.C., Kelly, W.R., Hwang, H.-H., 2006. Isotopic evidence of nitrate sources and denitrification in the Mississippi River, Illinois. J. Environ. Qual. 35, 495-504, http://dx.doi.org/10.2134/jeq2005.0012.

Peterson, B.J., Fry, B., 1987. Stable isotopes in ecosystem studies. Annu. Rev. Ecol. Syst. 18, 293-320, http://dx.doi.org/10.1146/annurev.es.18.110187.001453.

Pimentel, D., Kounang, N., 1998. Ecology of soil erosion in ecosystems. Ecosystems $1,416-426$.

Prins, T.C., Smaal, A.C., Dame, R.F., 1997. A review of the feedbacks between bivalve grazing and ecosystem processes. Aquat. Ecol. 31, 349-359.

Raymond, P.A., Bauer, J.E., 2001. Use of $14 \mathrm{C}$ and ${ }^{13} \mathrm{C}$ natural abundances for evaluating riverine, estuarine, and coastal DOC and POC sources and cycling: a review and synthesis. Org. Geochem. 32, 469-485, http://dx.doi.org/10.1016/ S0146-6380(00)00190-X.

Redfield, A.C., Ketchum, B.H., Richards, F.A., 1963. The influence of organisms on the composition of seawater. In: Hill, M.N. (Ed.), The Sea, Composition of SeaWater. Interscience, New York, pp. 26-77.

Robinson, D., 2001. $\delta^{15} \mathrm{~N}$ as an integrator of the nitrogen cycle. Trends Ecol. Evol. 16 153-162, http://dx.doi.org/10.1016/S0169-5347(00)02098-X.

Roegner, G.C., Seaton, C., Baptista, A.M., 2010. Climatic and tidal forcing of hydrography and chlorophyll concentrations in the Columbia River Estuary. Estuaries Coasts 34, 281-296, http://dx.doi.org/10.1007/s12237-010-9340-z.

Savage, C., 2005. Tracing the influence of sewage nitrogen in a coastal ecosystem using stable nitrogen isotopes. Ambio 34, 145-150, http://dx.doi.org/10.2307/ 4315573.

Savoye, N., David, V., Morisseau, F., Etcheber, H., Abril, G., Billy, I., Charlier, K., Oggian, G., Derriennic, H., Sautour, B., 2012. Origin and composition of particulate organic matter in a macrotidal turbid estuary: the Gironde Estuary, France. Estuarine Coastal Shelf Sci. 108, 16-28, http://dx.doi.org/10.1016/j. ecss.2011.12.005

Seitzinger, S.P., Harrison, J.A., Dumont, E., Beusen, A.H.W. Bouwman, A.F., 2005 Sources and delivery of carbon, nitrogen, and phosphorus to the coastal zone: an overview of Global Nutrient Export from Watersheds (NEWS) models and their application. Global Biogeochem. Cycles 19, 11.

Seitzinger, S.P., Kroeze, C., Bouwman, A.F., Caraco, N., Dentener, F., Styles, R.V., 2002a. Global patterns of dissolved inorganic and particulate nitrogen inputs to coastal systems: recent conditions and future projections. Estuaries Coasts 25 , 640-655.

Seitzinger, S.P., Sanders, R.W., Styles, R., 2002b. Bioavailability of DON from natural and anthropogenic sources to estuarine plankton. Limnol. Oceanogr. 47, 353-366.

Smith, B.N., Epstein, S., 1971. Two categories of ${ }^{13} \mathrm{C} /{ }^{12} \mathrm{C}$ ratios for higher plants 1 . Plant Physiol. 47, 380-384.

Smith, T.J., Anderson, G.H., Tiling, G., 2005. A Tale of Two Storms: Surges and Sediment Deposition from Hurricanes Andrew and Wilma in Florida's Southwest Coast Mangrove Forests. Science and Storms: The USGS Response to the Hurricanes of 2005 1, 169-174.

Smith, V.H., Tilman, G.D., Nekola, J.C., 1999. Eutrophication: impacts of excess nutrient inputs on freshwater, marine, and terrestrial ecosystems. Environ. Pollut. 100, 179-196, http://dx.doi.org/10.1016/S0269-7491(99)00091-3.

Sun, H., Han, J., Zhang, S., Lu, X., 2007. The impacts of "05.6" extreme flood event on riverine carbon fluxes in Xijiang River. Chin. Sci. Bull. 52, 805-812, http://dx. doi.org/10.1007/s11434-007-0111-6.

Sun, T., Macrander, A., Kaiser, D., 2014. A water movement study in Lianzhou Bay, Guangxi Province, China. J. Ocean Univ. China 13, 13-22, http://dx.doi.org/ 10.1007/s11802-014-1963-4.

Sweeney, R.E., Kalil, E.K., Kaplan, I.R., 1980. Characterisation of domestic and industrial sewage in Southern California coastal sediments using nitrogen, carbon, sulphur and uranium tracers. Mar. Environ. Res. 3, 225-243, http://dx. doi.org/10.1016/0141-1136(80)90029-X.

Syvitski, J.P.M., Vorosmarty, C.J., Kettner, A.J., Green, P., 2005. Impact of humans on the flux of terrestrial sediment to the global coastal ocean. Science 308, 376-380, http://dx.doi.org/10.1126/science.1109454.

Thornton, S.F., McManus, J., 1994. Application of organic carbon and nitrogen stable isotope and $\mathrm{C} / \mathrm{N}$ ratios as source indicators of organic matter provenance in estuarine systems: evidence from the Tay Estuary, Scotland. Estuarine Coastal Shelf Sci. 38, 219-233, http://dx.doi.org/10.1006/ecss.1994.1015.

Unger, D., Herbeck, L.S., Li, M., Bao, H., Wu, Y., Zhang, J., Jennerjahn, T., 2013. Sources, transformation and fate of particulate amino acids and hexosamines under varying hydrological regimes in the tropical Wenchang/Wenjiao Rivers and Estuary, Hainan, China. Cont. Shelf Res. 57, 44-58, http://dx.doi.org/ 10.1016/j.csr.2012.02.014.

Van Mooy, B.A.S., Keil, R.G., Devol, A.H., 2002. Impact of suboxia on sinking particulate organic carbon: enhanced carbon flux and preferential degradation of amino acids via denitrification. Geochim. Cosmochim. Acta 66, 457-465, http://dx.doi.org/10.1016/S0016-7037(01)00787-6. 
Wada, E., Imaizumi, R., Takai, Y., 1984. Natural abundance of ${ }^{15} \mathrm{~N}$ in soil organic matter with a special reference to paddy soils in Japan: biogeochmical implications on the nitrogen cycle. Geochem. J. 18, 109-123.

Wang, X., Ma, H., Li, R., Song, Z., Wu, J., 2012. Seasonal fluxes and source variation of organic carbon transported by two major Chinese Rivers: the Yellow River and Changjiang (Yangtze) River. Global Biogeochem. Cycles 26, GB2025, http://dx. doi.org/10.1029/2011GB004130.

Wu, D., Wang, Y., Lin, X., Yang, J., 2008. On the mechanism of the cyclonic circulation in the Gulf of Tonkin in the summer. J. Geophys. Res., 113, http: //dx.doi.org/10.1029/2007JC004208.

Wu, Y., Dittmar, T., Ludwichowski, K.U., Kattner, G., Zhang, J., Zhu, Z.Y., Koch, B.P. 2007. Tracing suspended organic nitrogen from the Yangtze River catchment into the East China Sea. Mar. Chem. 107, 367-377.

www.nanning.gov.cn, 2010. Guangxi Beibu Gulf Economic Zone Development Scheme [WWW Document]. 〈www.nanning.gov.cn〉. URL 〈http://www.nan ning.gov.cn/n725531/n751804/n752421/n1556201/7855550.html $\rangle$ (accessed 9. 17.12).

Xu, J., Glibert, P., Liu, H., Yin, K., Yuan, X., Chen, M., Harrison, P., 2012. Nitrogen sources and rates of phytoplankton uptake in different regions of Hong Kong waters in summer. Estuaries Coasts 35, 559-571, http://dx.doi.org/10.1007/ s12237-011-9456-9.
Yu, F., Zong, Y., Lloyd, J.M., Huang, G., Leng, M.J., Kendrick, C., Lamb, A.L., Yim, W.W.-S. 2010. Bulk organic $\delta^{13} \mathrm{C}$ and $\mathrm{C} / \mathrm{N}$ as indicators for sediment sources in the Pearl River delta and estuary, southern China. Estuarine Coastal Shelf Sci. 87, 618-630, http://dx.doi.org/10.1016/j.ecss.2010.02.018.

Yuan, X., Glibert, P., Xu, J., Liu, H., Chen, M., Liu, H., Yin, K., Harrison, P., 2012. Inorganic and organic nitrogen uptake by phytoplankton and bacteria in Hong Kong waters. Estuaries Coasts 35, 325-334, http://dx.doi.org/10.1007/s12237011-9433-3.

Zhang, J., Liu, S.M., Xu, H., Yu, Z.G., Lai, S.Q., Zhang, H., Geng, G.Y., Chen, J.F., 1998 Riverine sources and estuarine fates of particulate organic carbon from North China in late summer. Estuarine Coastal Shelf Sci. 46, 439-448, http://dx.doi. org/10.1006/ecss.1997.0277.

Zhang, J., Wu, Y., Jennerjahn, T.C., Ittekkot, V., He, Q, 2007. Distribution of organic matter in the Changjiang (Yangtze River) Estuary and their stable carbon and nitrogen isotopic ratios: implications for source discrimination and sedimentary dynamics. Mar. Chem. 106, 111-126.

Zhang, S., Gan, W.-B., Ittekkot, V., 1992. Organic matter in large turbid rivers: the Huanghe and its estuary. Mar. Chem. 38, 53-68, http://dx.doi.org/10.1016/ 0304-4203(92)90067-K.

Zhu, Q., Lowe, E.A., Wei, Y., Barnes, D., 2007. Industrial symbiosis in China: a case study of the Guitang group. J. Ind. Ecol. 11, 31-42, http://dx.doi.org/10.1162/ jiec.2007.929. 